\title{
Bone marrow in orthopaedics (part II): a three hundred and seventy million-year saga from the Devonian to the coronavirus disease 2019 pandemic - osteonecrosis; transplantation; "human chimera"; stem cells, bioreactors, and coronavirus disease
}

\author{
Philippe Hernigou ${ }^{1}$ (D) \\ Received: 26 September 2020 / Accepted: 29 September 2020 / Published online: 9 October 2020 \\ (C) SICOT aisbl 2020
}

\begin{abstract}
Purpose Three hundred seventy million years ago, bone marrow appeared in skeleton of a fish. More than one hundred years ago, the concept of bone marrow transplantation was proposed to treat human diseases. During the last five decades, this concept became a reality first in hematology and later for orthopaedic diseases.

Material and methods These advances were possible due to the comprehension of the three major components of bone marrow: the fat part, the haematologic part, and the stroma part. Each part has a different history, but the three parts are linked in physiology as in history.

Results During many centuries, bone marrow was considered just as food; however, one hundred years ago, the concept of bone marrow transplantation to treat humans was proposed by the French physician Brown-Séquard. During the last five decades, this concept became a reality first in haematology and later for orthopaedic diseases. Transferring what was known from experimental animal models to humans was met with many challenges, the atomic bomb research, and many deaths. Yet through the recognition and subsequent understanding of fundamental processes, medical resiliency, and the determination of a few pioneers, local bone marrow transplantation in orthopaedic surgery became a therapeutic option first for a limited number of diseases and patients. Over the last two decades, mesenchymal stromal cells (MSCs) have been the focus of intense research by acadaemia and industry due to their unique features. MSCs can be easily isolated and expanded through in vitro culture by taking full advantage of their self-renewing capacity. In addition, MSCs exert immunomodulatory effects and can be differentiated into various lineages, which makes them highly attractive for clinical applications in cell-based therapies.

Conclusion In this review, we attempted to provide a historical overview of bone marrow history, MSC discovery, characterization, and the first clinical studies conducted.
\end{abstract}

Keywords Bone marrow history $\cdot$ Stem cells $\cdot$ Osteonecrosis $\cdot$ Marrow transplantation $\cdot$ Tissue engineering

What is the relation between a 370-million-year-old fish, osteonecrosis, "The Irish Iliad", the neurologist BrownSéquard, the Milano Ossobucco, Einstein, Hiroshima, and tissue engineering in orthopaedic surgery? It is just bone marrow. After description of the bone marrow history in traumatology [1], this article is a short history of bone marrow

Philippe Hernigou

philippe.hernigou@wanadoo.fr

1 Orthopedic Department Henri Mondor Hospital, University Paris East, Paris, France that focuses rather on orthopedics, but of course summarizes also some hematologic aspects. Bone marrow has three major components: the fat part, the hematologic part, and the stroma part. Each part has a different history, but the three parts are linked in physiology as in history. This paper is designated to orthopaedic surgeons who every day are dealing with bone marrow when performing surgery as simple as nailing or arthroplasty and who may not know the extraordinary properties and the "History" of bone marrow. Where to begin? As the King said in Lewis Carroll's Alice in Wonderland [2]: "Begin at the beginning, go on till you come to the end: then stop" (Fig. 1). 
The White Rabbit put on his spectacles. "Where shall I

begin, please your Majesty?" he asked.

"Begin at the beginning," the King said gravely, "and go on till you come to the end: then stop."

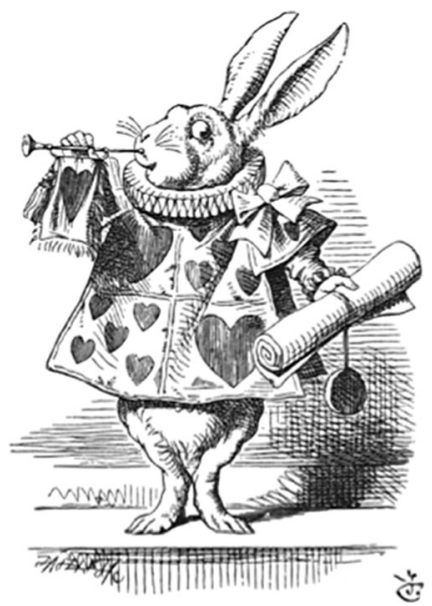

Fig. 1 The White Rabbit is the spark of curiosity that activates Alice's spiritual awakening. It is the White Rabbit who leads Alice down the rabbit hole. It is the White Rabbit which Alice runs after and searches for endlessly in Wonderland, a symbol of her quest for knowledge as many scientists for the bone marrow

\section{Bone marrow occurrence in a 370-million-year-old fish during the Devonian period}

Bone marrow was found to be present for the first time in the Devonian period. The period is named after Devon, a county in southwestern England, where a controversial argument in the 1830 s, over the age and structure of the rocks found distributed throughout the county, was eventually resolved by the definition of the Devonian period in the geological timescale. Another common term of this period is "Age of the Fishes," referring to the evolution of several major groups of fish that took place during the period.

Bone marrow is only present in skeleton of mammalian and birds; this presence in bone is related to the period when amphibians and tetrapods were conquering earth. As these terrestrial animals had to deal with a sixfold higher gravity in comparison with marine animals living in water milieu, bone structure changed to adapt with occurrence of medullary cavity in long bones and decrease weight of bones. What was unknown is at which period bone marrow arrived in long bones?

But on March 2014, a French and Swedish team of researchers [3] have presented the earliest fossil evidence for bone marrow presence in the fin of a 370-million-year-old fish. They discovered that Eusthenopteron, a Devonian (370million-year-old) lobe-finned fish from Miguasha in Canada that is closely related to the first tetrapods, already exhibited typical marrow processes inside its humerus (Fig. 2). These processes are longitudinal and connect to the shoulder and elbow joint surfaces of the humerus; the bone marrow certainly played a role in elongation of fin bone through complex interactions with the trabecular bone. That represents a pivotal stage in a landmark event in the history of life on Earth — the transition of fish to land vertebrates. Inside the tip of tetrapod front fins - called pectoral fins - were tiny bones called radial bones arranged in a series of rows like digits - the precursor to fingers. These would have provided the flexibility for fin to bear weight on land.

This discovery is important to understand the evolutionary steps that have built up the architecture of tetrapod bones and created a location for the complex and important tissue that is bone marrow. Long bones of tetrapods are not only important for locomotion, but also they host the bone marrow. The latter plays a major role in osteogenesis and in haematopoiesis. In adults, about one hundred billion to around one trillion of new blood cells are produced each day to maintain a stable blood circulation.

\section{Bone marrow and osteonecrosis: a history of $\mathbf{2 5 0}$ million years}

One of the oldest diseases in the world is probably osteonecrosis if we except fracture.

\section{First osteonecrosis: $\mathbf{2 5 0}$ million years ago, resulting from extent reptiles (continuing diving)}

Bone marrow tissue is found widely in the bones of reptiles, including the vertebral bodies. Diving habits of Mesozoic marine reptiles have been characterized on the basis of a unique pathology, caused by decompression, avascular necrosis. The ichthyopterygians (Fig. 3) were marine reptiles which appeared 250 million years ago and became extinct 90 million years ago [4]. From the Late Triassic, they developed a fish- or dolphin-like body shape. In total, 16-20\% of their humerus revealed signs of avascular bone necrosis (Fig. 3). Avascular necrosis was the result of bone death caused by embolisms resulting from intravascular bubble formation during decompression. The reason is that after conquering earth, extent reptiles have continued to dive as fishes during a long period. One of the characteristics of the reptile heart is a right-left shunt, and it is suggested that this could contribute to the high frequency of decompression illness in the extinct reptiles. As nitrogen is free and not bounded to haemoglobin as oxygen, and also more soluble in fat, larger volumes of nitrogen will dissolve in the fatty marrow of the shafts of the long bones. During decompression after deep diving, the absorbed nitrogen changes from dissolved phase to free phase and gas bubbles may be formed in the tissues. It has been long recognized that rapid decompression will cause nitrogen to come out of solution and form bubbles (Fig. 4). Intravascular bubbles may obstruct and distend the vascular sinusoids of the fatty bone marrow of the long bones and be the cause of bone pain in the upper and lower limbs. Normally during decompression, bubbles are formed in the venous circuit, and normally, the lung is 
Fig. 2 Researchers from Uppsala University in Sweden and the European Synchrotron Radiation Facility (ESRF) in France decided to look for the origin of the bone marrow within vertebrates, using synchrotron microtomography to investigate the interior structure of fossil long bones without damaging them. They discovered that Eusthenopteron, a Devonian (370-million-year-old) lobefinned fish from Miguasha in Canada that is closely related to the first tetrapods, already exhibited typical marrow processes inside its humerus (upper arm bone)

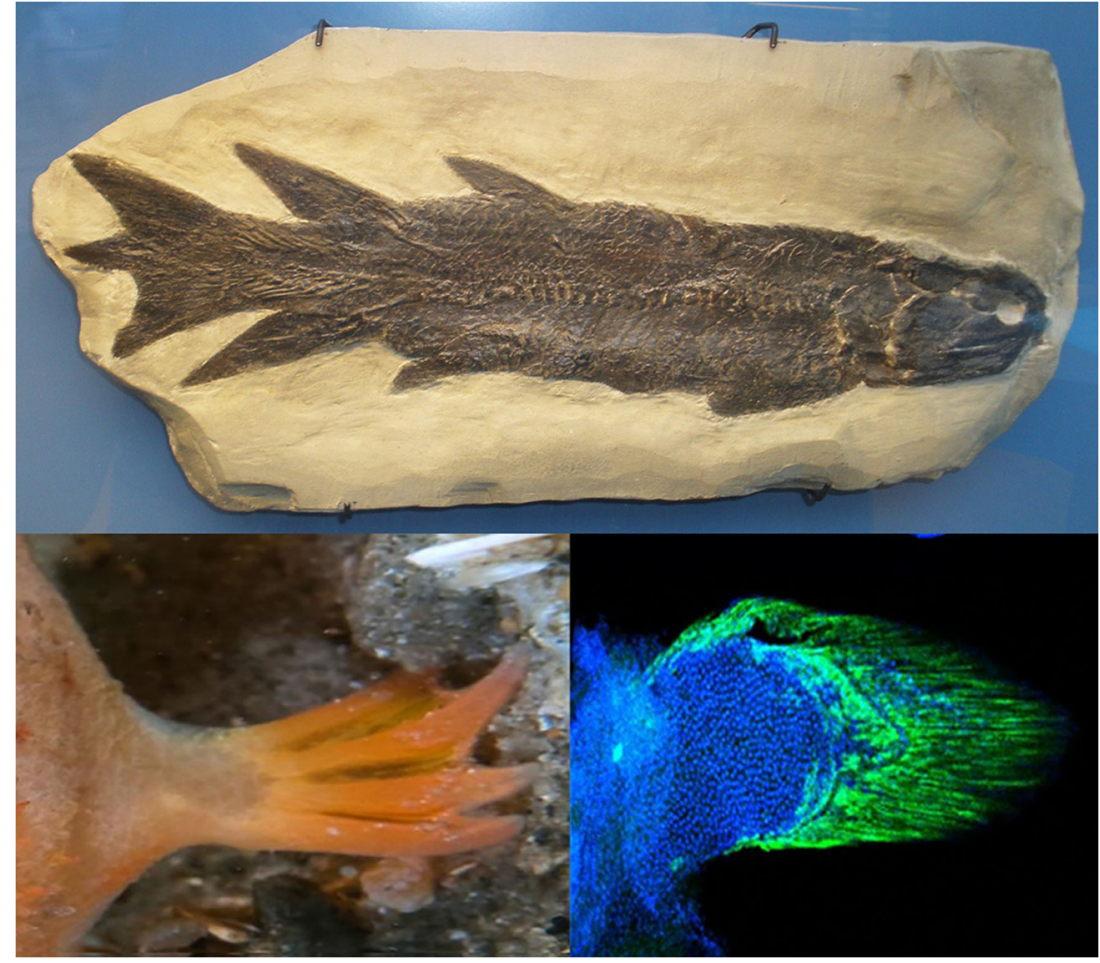

very effective as a filter when the systemic and pulmonary circuit are fully separated which has occurred during evolution for mammals as whales. But, an opening in the heart with possibility of right to left shunting (as in reptiles) allows venous nitrogen-oversaturated blood to flow into the systemic circulation (Fig. 5). When the blood is shunted away from the lung because of a right-left shunt of the reptile heart, bubbles can spread to the arterial system leading to air-embolism in arterioles and causing avascular episodes in the brain and the bones. These bubbles can compromise the vascularization and feeding of bone if they are present in the arterial system.

\section{Osteonecrosis in human divers}

\section{Osteonecrosis before knowledge of "dive tables"}

In 1911, Bornstein and Plate [5], followed later and independently by Bassoe in 1913 [6], presented radiological

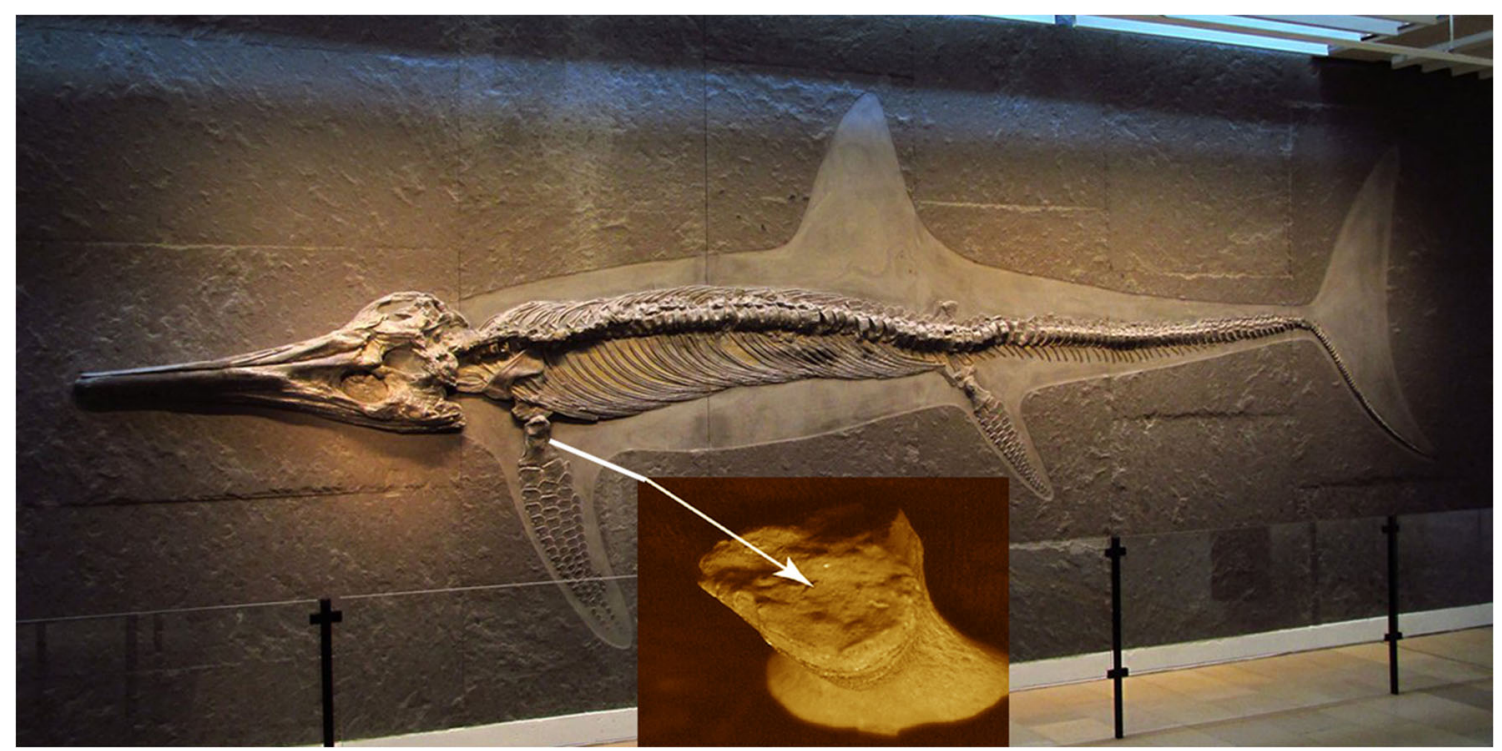

Fig. 3 Large skeleton of the ichthyosaur Temnodontosaurus from the Lower Jurassic of Holzmaden. On display at the Urweltmuseum Hauff in Holzmaden (Germany). Bone osteonecrosis of the humerus 


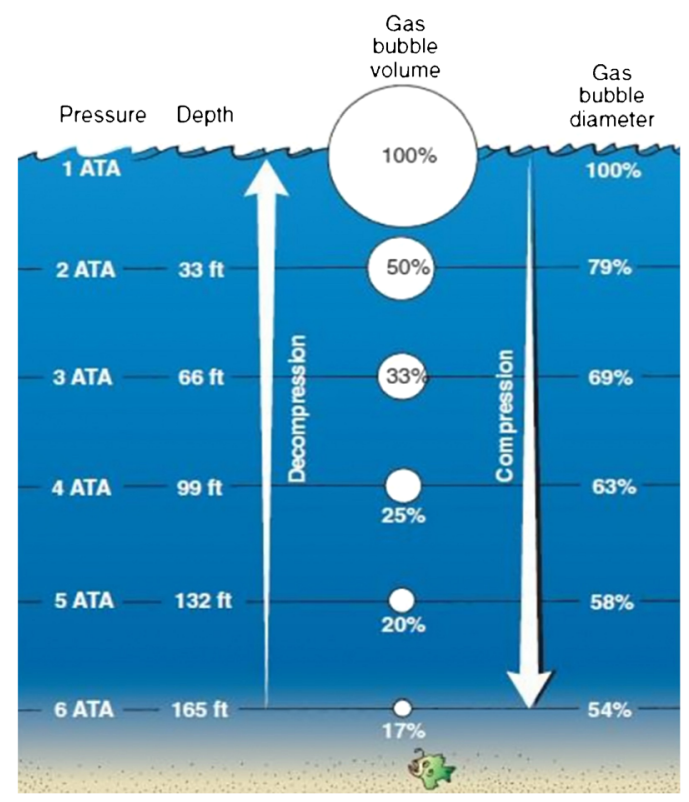

Fig. 4 Illustration of bubble formation process in divers; another representation could be a bottle of carbonated soda. A bottle of carbonated soda is filled with gas (carbon dioxide), which cannot be seen because it is dissolved in solution under pressure. When the bottle is opened, the pressure is released and the gas leaves the solution in the form of bubbles. A diver returning to the surface is similar to opening the

confirmation of aseptic necrosis of bone in compressed air workers. The first report of aseptic necrosis in an underwater diver subsequently appeared in 1936 [7]. Often called "the bends," decompression sickness happens when a scuba diver ascends too quickly. Divers breathe compressed air that contains nitrogen. The air composition is $78 \%$ nitrogen. At higher pressure under water, the nitrogen gas goes into the body's tissues. This does not cause a problem when a diver is down in the water. And if a diver rises to the surface (decompresses) at the right rate, the nitrogen can slowly and safely leave the body through the lungs. But if a diver rises too quickly, the nitrogen forms bubbles in the body. Intravascular bubbles may obstruct and distend the vascular sinusoids of the fatty bone marrow of the long bones and be the cause of bone pain in the upper and lower limbs. This can cause tissue and nerve damage. In extreme cases, it can cause paralysis or death if the bubbles are in the brain. The bends, also known as decompression sickness (DCS) or Caisson disease, occurs in scuba divers or high altitude or aerospace events when dissolved gases (mainly nitrogen) come out of solution in bubbles and can affect just about any body area including joints, lung, heart, skin, and brain.

\section{Osteonecroses in human with foramen ovale (heritage of reptiles)}

The risk of decompression illness is directly related to the depth of the dive, the amount of time under pressure, and
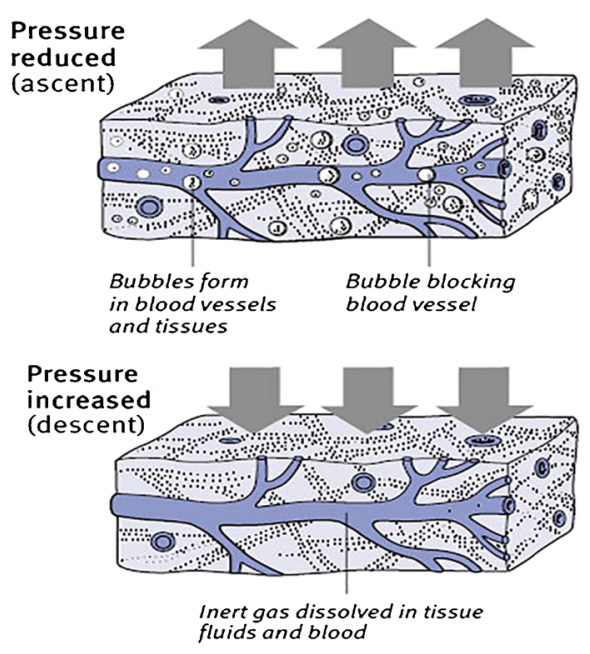

bottle of soda. As a diver swims to the surface, the pressure decreases. The nitrogen, which has dissolved in tissues, wants again to leave, because the body can hold only a certain amount based on that nitrogen pressure. If a diver surfaces too fast, the excess nitrogen will come out rapidly as gas bubbles. Depending on which organs are involved, these bubbles produce the symptoms of decompression sickness

the rate of ascent. Dive tables, such as the U.S. Navy Dive Tables, provide general guidelines as to what depths and dive times are less risky for the development of decompression sickness. In humans, DCS is seen among scuba divers and compressed air workers where the uptake of nitrogen in the blood and tissues is continuously taking place. If appropriate, decompression procedures have not been used; these divers and workers will be at risk for avascular bone necrosis. If the guidelines of dive tables are respected, there is from a theoretical point of view no risk, except in one situation; the human heart has four chambers, and the systemic and pulmonary circuit is normally fully separated. In the fetal life, the left and the right atrium communicate with one another through the foramen ovale. This opening closes during the first weeks of life. In fetal life, the lungs are not functioning and the fetal blood is oxygenated in the placenta. In the atrium, $60 \%$ of the blood is shunted from the right to left side (R-L shunt). In some individuals, this intracardiac opening is persistent to some degree in adult life as a patent foramen ovale (PFO). Small- and medium-size openings are normally symptomless and may be present in as many as $30 \%$ of normal subjects. It is important to know that even divers [8] who follow decompression schedules and tables may still experience DCS. In humans, the risk of decompression illness is five times increased in individuals with patent foramen ovale (Fig. 5); this condition allows blood shunting from the venous circuit to the systemic circuit. There is convincing evidence for the connection between PFO and DCI in divers. Torti et al. [9] found that 

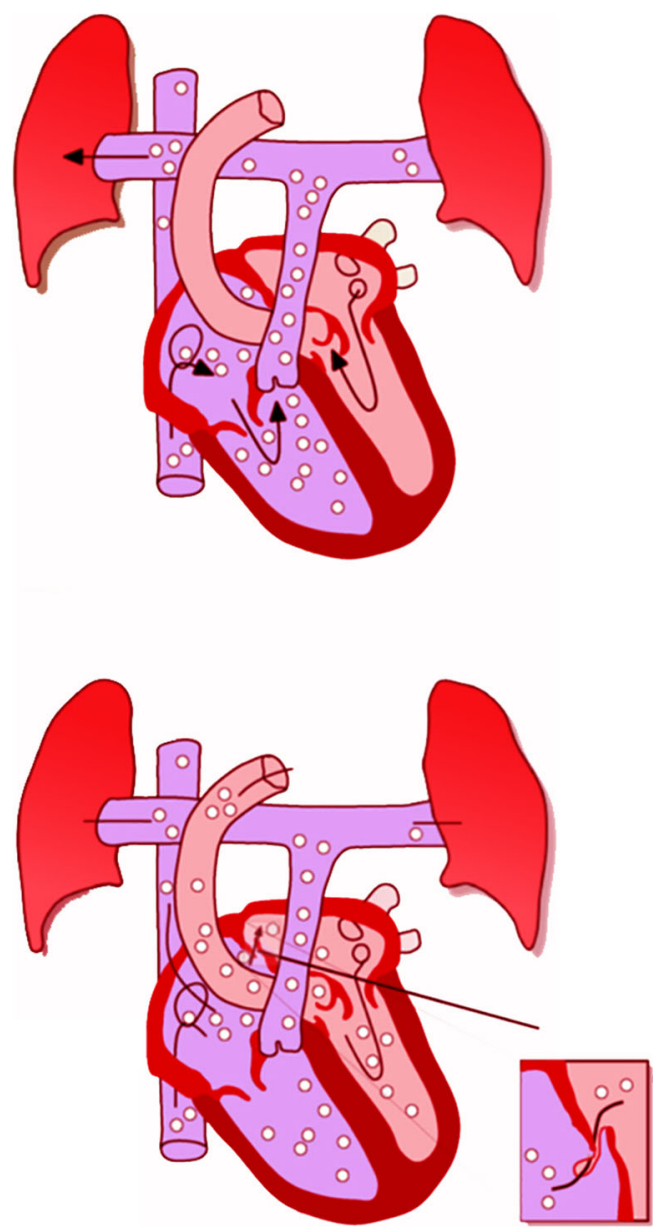

Fig. 5 Paradoxical gas embolism. Schematic drawing demonstrating the paradoxical gas embolism in a diver with a patent foramen ovale; migration of a bubble of gas from the venous system to the left atrium via a PFO, with subsequent systemic embolization

PFO was correlated with a five times increased risk of major DCI events and the risk augments with the PFO size. Situations that elevate right atrial pressure relative to left atrial pressure would increase the tendency for any right to left shunting, such as breath holding and coughing, and the Valsalva-like activity, often used by divers to equilibrate the pressure in the middle ear, will increase the pressure in the right atrium and thereby increase the right-left shunt if PFO is present.

\section{Fat in bone marrow: from food to a cause of bone diseases}

Think about bones: what images come to your mind? Perhaps a skeleton or a skull; or Adam rib producing Eve; or the strong bone limbs. But your skeleton hides a secret: it is full of fat, and no one knows why!

\section{Aspiration of bone marrow: not only with trocar!}

Bone marrows of animals have been used by humans as food in many cultures. Some anthropologists think that humans were scavengers in early times (rather than hunters) in some parts of the world. Marrow would have been a useful source of food (largely due to its fat content) for hominids using tools, capable of breaking the bones of the carcasses left by major predators, such as lions.

European diners in the eighteenth century often used a marrow scoop (or marrow spoon). In China, the pork tibia is used to make slow-cooking soup, with one or both ends of the tibia cut. In some restaurants, the cooked pork tibia would be served with a straw specially to suck the semi-liquefied marrow. The author admits some personal experience in bone marrow aspiration with a trocar from the iliac crest but also with a straw as in Fig. 6.

In Hungary, tibia is the main ingredient in meat soup; the bone is cut into 10 - to $15-\mathrm{cm}$ pieces and the ends are covered with salt to prevent the bone marrow from escaping from the bone during cooking. Beef bone marrow is also the main ingredient in the Italian dish "Ossobuco" (braised veal shank), and beef bone marrow is often included in French broth in a stew, cooked marrow traditionally eaten on toast with peppered salt. In Iranian cuisine, lamb shanks are often broken before cooking to allow customers to soak and eat the marrow when the dish is served. Similar practices are also common in Indian, Pakistani, and Lebanese cuisine. And who can dispute

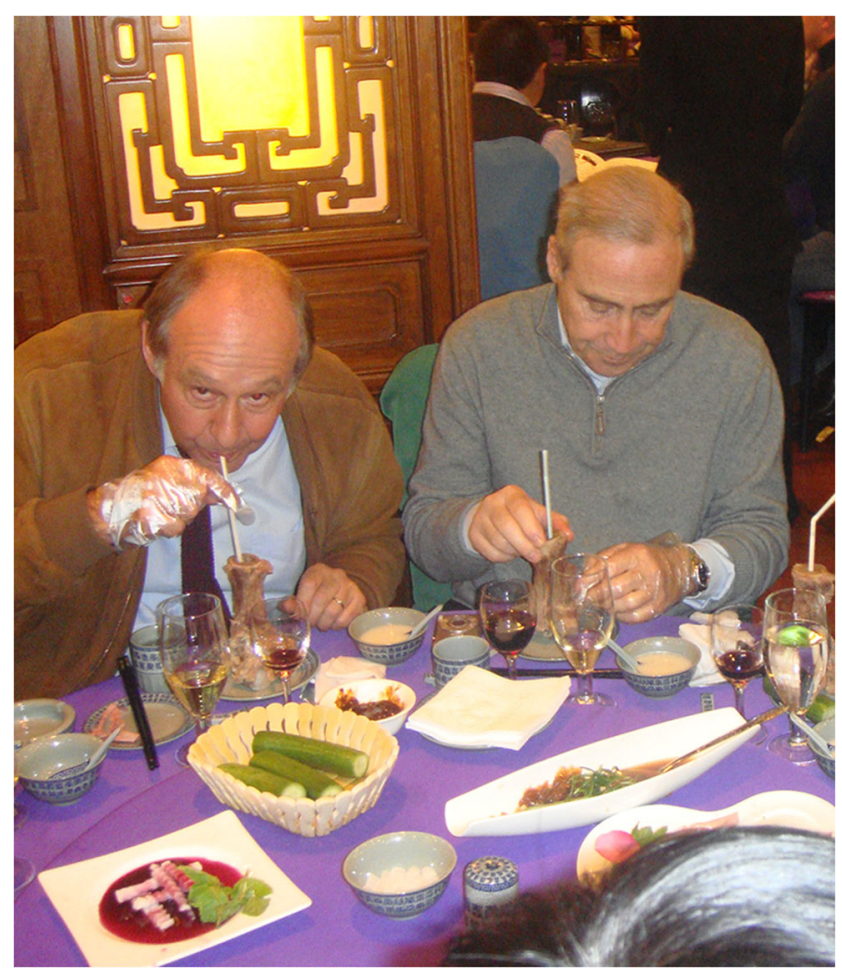

Fig. 6 The author and one friend (Dr. Bercovy) in China; the cooked pork tibia is served with a straw specially to suck the semi-liquefied marrow 
the attractiveness of bone marrow on toast on a cold winter's day. A good red French vine helps (the author admits some preference, without any conflict of interest).

\section{The mystery of the relation between the marrow adipocyte and the skeleton}

Prior to the interest to bone marrow adipose tissue [10], adipose tissue was considered to be a metabolically inert organ whose function was solely for the storage of triglyceride, protection, insulation, and cosmetic importance. Composed of mature adipocytes, endothelial cells, immune cells, pre-adipocytes, and adipose progenitor/stem cells (stromal vascular fraction), mammalian adipose tissue is typically classed as two distinct subtypes, white adipose tissue (WAT) or brown adipose tissue (BAT).

Identified over a century ago [11], marrow adipose tissue (MAT) is situated within the marrow cavity in a distinct and organized manner. It has been noticed from a scientific point of view over a century ago that bone marrow contains "fatstoring" cells, called adipocytes. Having adipocytes in our bones might strike you as unusual, and this unsolved mystery is surprising: Marrow cavities in all the bones of newborn mammals contain active haematopoietic tissue, known as red bone marrow to produce red cells in blood. From the early postnatal period onwards, the hematopoietic tissue, mainly in the bones of the extremities, is gradually replaced by nonhaematopoietic mesenchymal cells that accumulate lipid drops, known as yellow or fatty bone marrow. This conversion from yellow marrow to bone marrow adipose tissue (MAT) develops rapidly during puberty [12] such that, by the time we reach adulthood (Fig. 7), it can comprise up to $70 \%$ of bone marrow volume; this represents over $8 \%$ of total fat mass!
Marrow adipose tissue show a similar distribution in rodents and other animals, predominating in the arms and legs but being sparse (or non-existent) in the spine and more central skeleton [13]. Largely overlooked since its discovery, MAT was not recognized as an adipose depot until the midlate twentieth century [14] and MAT research began to attract further interest only in the 1970s, when it was shown that the developmental origin and lipid composition of marrow adipocytes is distinct to that of white adipocytes $[15,16]$.

MAT is not distributed uniformly around the skeleton, but instead predominates in the arms and legs. Furthermore, MAT subtypes differ in lipid composition and gene expression [17]. The current thinking is that the origin of MAT is distinct to that of other adipose tissue (WAT and BAT). Marrow adipose tissue is thought to be derived from progenitors that express osterix (Sp7), a transcription factor essential for osteoblastogenesis and bone formation in mice, which may explain the skeletal regulation with the adipocyte of bone marrow.

\section{Skeletal regulation by bone marrow adipose tissue}

\section{Expansion of bone marrow adipose tissue}

In pathological conditions such as anorexia nervosa, MAT is elevated [18]. This accumulation of adipose tissue is somewhat counter-intuitive given that in catabolic states other depots of adipose tissue are being mobilized for energy utilization. The paradox to why this occurs remains unclear, but it has been suggested that MAT may occupy bone marrow (BM) cavity space for surviving starvation, with as consequence decrease of trabecular bone (Fig. 8). But as direct consequences for the orthopaedist, anorexia nervosa has a risk of pathologic fracture [19], as the phenomenon of aging which is also related to adipocytes.
Fig. 7 Bone marrow conversion from hematologic bone marrow (in children) to fat bone marrow in adult. In children, bone marrow supports only increasing haematopoiesis due to increasing size of children and contains no fat. When the size of the person is stable with a steady-state haematopoiesis, the bone marrow accumulates fat cells. However, in young adults under conditions of increased haematopoietic requirement, they lose fat and regain their ability to support haematopoiesis

\section{Normal bone marrow conversion}
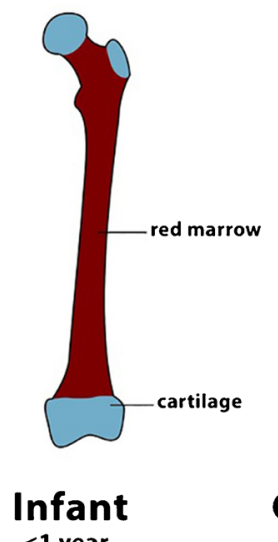

Infant

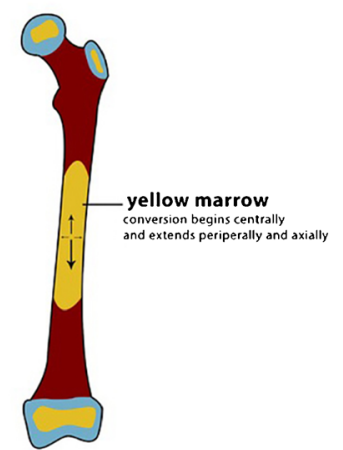

Childhood

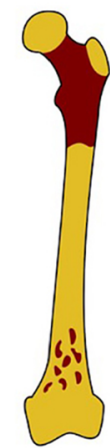

Adolescent 10-20 years

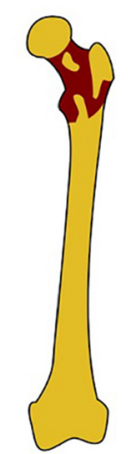

Adult $>25$ years 
Fig. 8 The anatomical distribution, clinical associations, and potential functions of bone marrow adipose tissue (MAT)

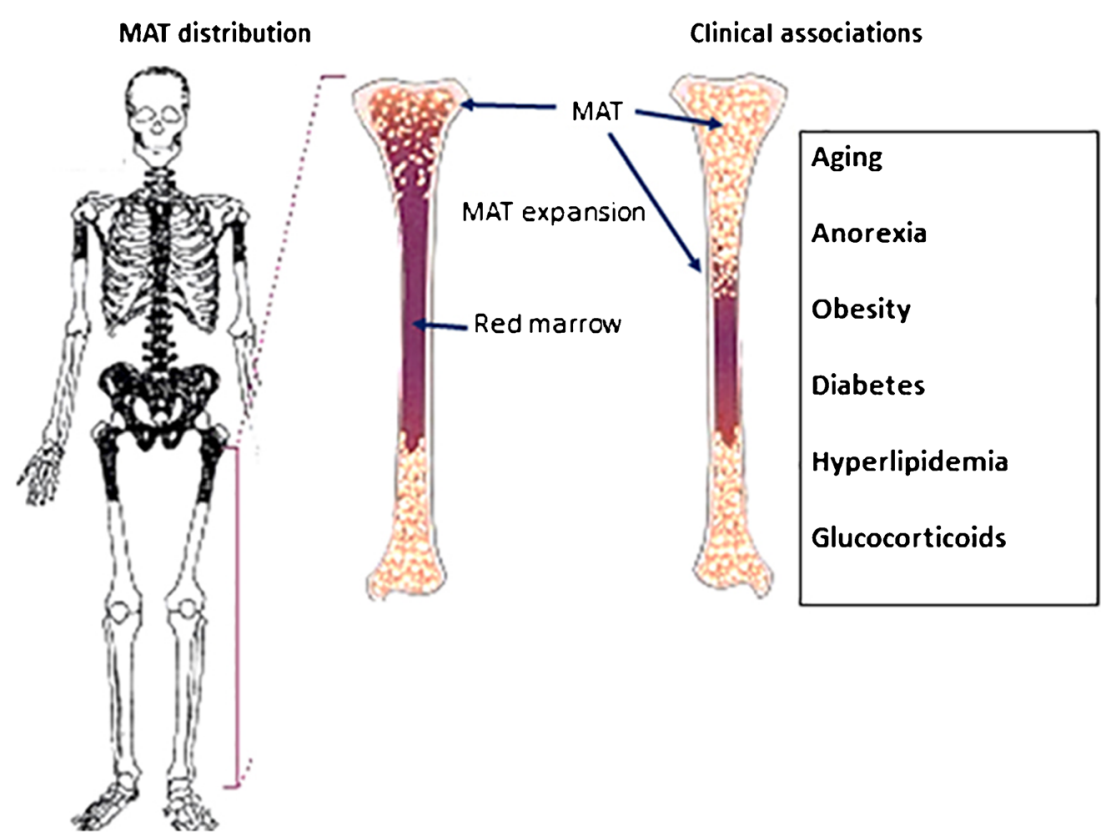

Moreover, MAT increases during treatment with pharmacologic agents such as glucocorticoids. Glucocorticoids have antiproliferative and anti-inflammatory properties and are exploited and successfully used clinically in treating disorders of heightened immunity and autoimmune diseases. Exogenous glucocorticoid administration in humans results in femoral MAT expansion that is correlated with steroid intake [20]. It is also of note that in states of glucocorticoid excess, there is an increased risk of hip osteonecrosis [21] that can be corrected with local mesenchymal stem cell (MSC) injection.

\section{Decline of bone marrow adipose tissue}

In contrast to MAT expansion, far less is currently known about the decline of MAT. The best example is "Gaucher disease" which is a genetic disorder in which glucocerebroside, a sphingolipid (known as glucosylceramide), accumulates in cells of some organs (Fig. 9). This disease was described in 1882 by a French doctor Philippe Gaucher (Fig. 10), who lent his name to the condition, in his thesis [22]. Gaucher's disease is an autosomal-recessive inherited disorder caused by a deficiency or absence of $\beta$-glucocerebrosidase ( $\beta$-glucosidase). Infiltration of the BM by lysosome-engorged macrophages (Gaucher cells) results in secondary damage to the bone, including mild osteopenia and osteonecrosis.

Postmenopausal women receiving estrogen replacement show decreased BM adipocyte number and size, as well as decreased MAT, suggesting that locally generated androgens and oestrogens can exert regulatory action on bone marrow cells. At the end, contrary to the high number of researches on the haematologic bone marrow and on mesenchymal stem cells, many questions remain unanswered for fat in bone marrow.

\section{Irish legend of bone marrow transplantation 2500 years ago to heal wounds}

Scientific interest in bone marrow transplants began in the twentieth century [23], and the possibility to improve healing of wounds by mesenchymal stem cells was only reported in

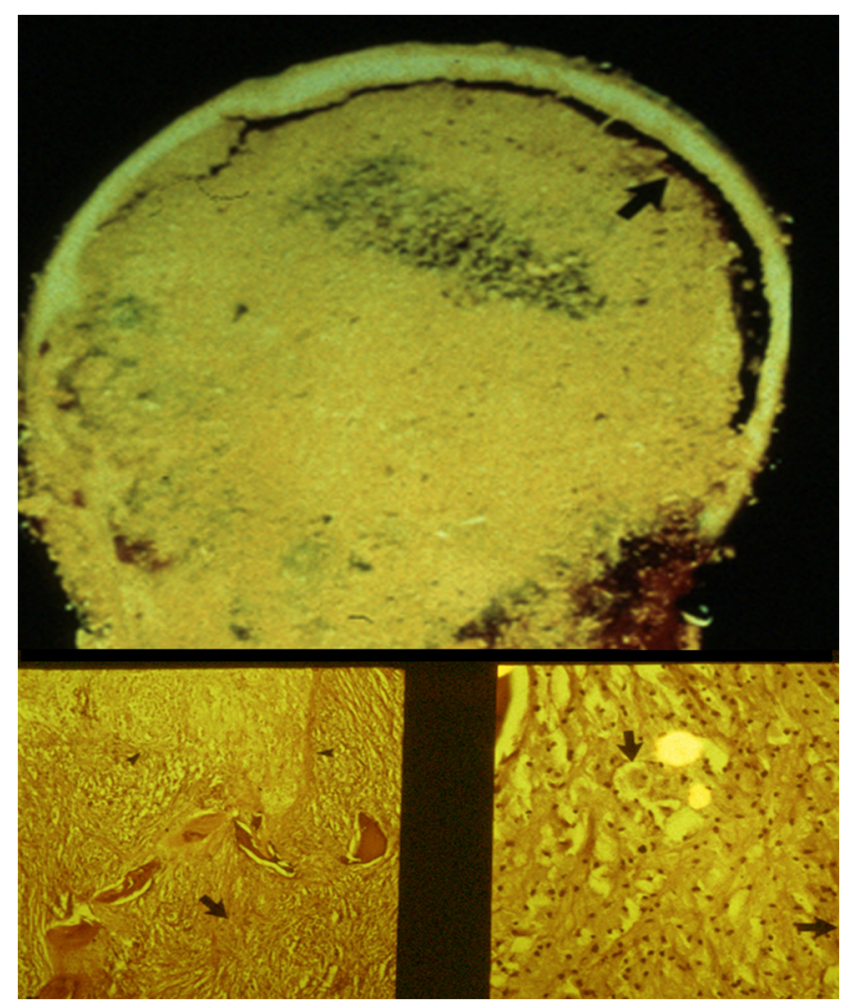

Fig. 9 Cross section of the femur head. The microscopic pictures below highlight the yellowish areas consisting of vital bone and marrow filled with confluent sheets of Gaucher cells (arrows) 


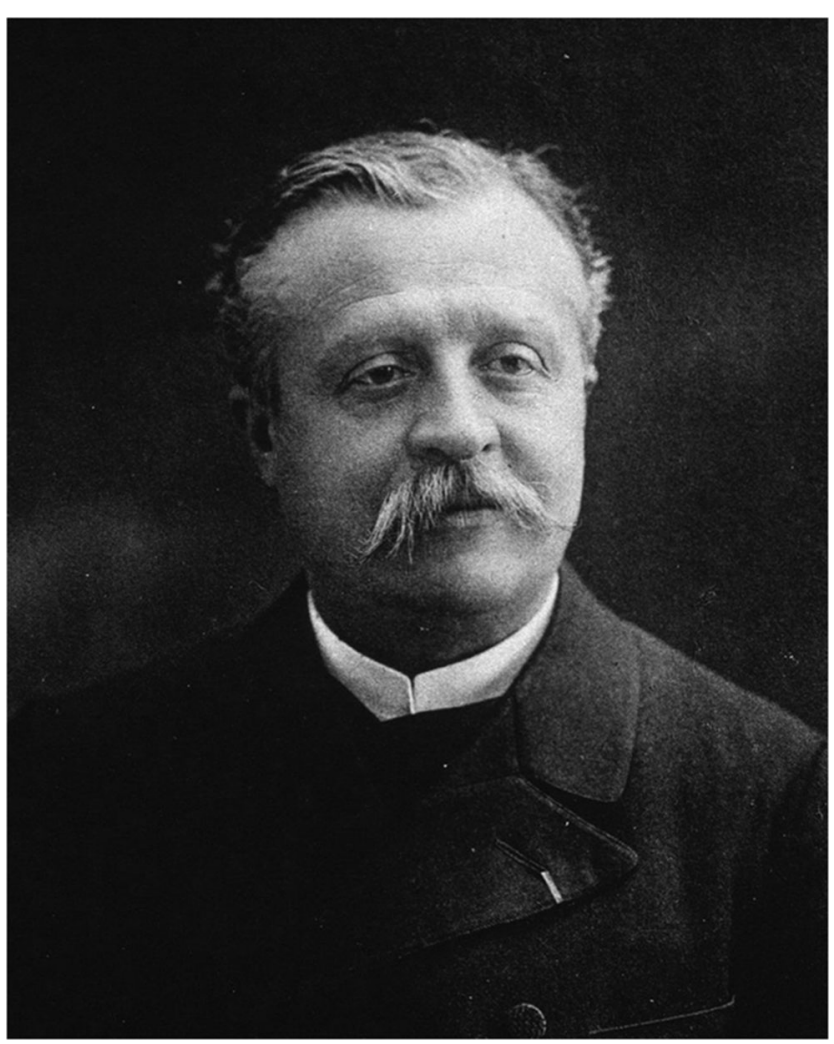

Fig. 10 Portrait of Philippe Gaucher

the twenty-first century. However, the eighth century legend shows that one of the first records of bone marrow transplants can be found in an epic cycle of heroic Irish stories from the eighth century [24]. It is the story of an invasion of cattle by the armies of Queen Medb (Maeve) and King Ailill when they tried to steal Cuailgne's big brown bull. The departure of Cooley's cows, commonly known as The Cattle Raid of Cooley, is an epic of ancient Irish literature that is often referred to as "Irish Iliad" or Táin. Traditionally in the first century, in a heroic pre-Christian era, Táin is the central text of a group of short stories known as the Ulster Cycle. It is preserved in three written versions or "reviews" in twelfthcentury manuscripts, and later the first compilation is largely in Old Irish, the second in a more consistent work in Middle Irish, and the third in a modern Irish version.

Táin had a great influence on Irish literature and culture. The Táin Bó Cúailgne (The Cattle Raid of Cooley) written around $100 \mathrm{AD}$, describes Cethern, a badly wounded warrior who in about $500 \mathrm{AD}$ was advised by Fingin, a healer, to bathe in a vessel of bone marrow. He was miraculously healed and returned to avenge his enemies. It contains the following description: "Fingin, the prophetic leech, asked Cuchulain for a barrel of marrow to heal and heal Ceithern mac Fintan." Cuchulain went to the camp and to the roots of Erin's men, and whatever he found of flocks and flocks, he took with him. And he made puree (Fig. 11) from his flesh, bones, and skin, and Cethern, the son of Fintan, was taken to the marrow bath for three days and three nights, and his flesh began to drink in the marrow around him, and the marrow went into his stitches and cuts, and his many wounds. Then after three days and three nights, he got out of the marrow bath (Fig. 12), with healed wounds. This is a very early description of the bone marrow to improve stromal tissue repair and the first description of xenotransplantation (from animal to human). According to the reader's scientific level, the Irish marrow transplantation may be considered as a legend or a scientific paper: Fingin claimed success (or at least a proof of concept) and set a continuous precedent for claiming efficacy based on questionable study designs and quick follow-up... To shorten the protocol discussion, in a warning, Cethern killed 49 doctors who recommended other therapies before advocating a bone marrow cure. Today, they is still some debate about the use of bone marrow as treatment for orthopedic diseases, and more discussions about the protocol, but those doctors who do not recommend this treatment are not killed.

\section{Bone marrow as medication at the end of the nineteenth century}

\section{Brown-Séquard proposed bone marrow as treatment for haematologic diseases}

In the nineteenth century, the French physician CharlesEdouard Brown-Sequard [25] described giving calf's' bone marrow to women with chlorosis or green sickness (hypochromic anaemia) seen in listless women and virgins. He dissolved the bone marrow in glycerol (killing any living cells) and gave it to Parisian women by mouth. Brown-Séquard (Fig. 13) rightly claimed success, but his explanation of how his elixir worked may have been a bit off; it was apparently sufficiently convincing: physicians and apothecaries gave bone marrow extracts from various creatures (Fig. 14) to treat diverse illnesses and complaints, often with remarkable success. As expected, these women recovered probably due to the amount of iron in the extract rather than the virtue of cells. BrownSequard rightly claimed success but his explanation of how his elixir worked may have been exaggerated. He was a controversial and eccentric man known for "self-reporting rejuvenated sexual prowess" after having eaten some "extracts of monkey testes".

Despite Brown-Séquard was a controversial and eccentric man, he was the first to propose to use bone marrow to treat leukaemia! Brown-Séquard and d'Arsonval, as early as 1891, suggested its use in the treatment of leukaemia and other diseases believed to be characterized by defective haemogenesis. This was reported in a discussion on the use of bone marrow that was outlined in 1896 by Quine in the Chairman's address of the Journal of the American Medical Association (Fig. 15), where he discussed the "remedial application of bone marrow 


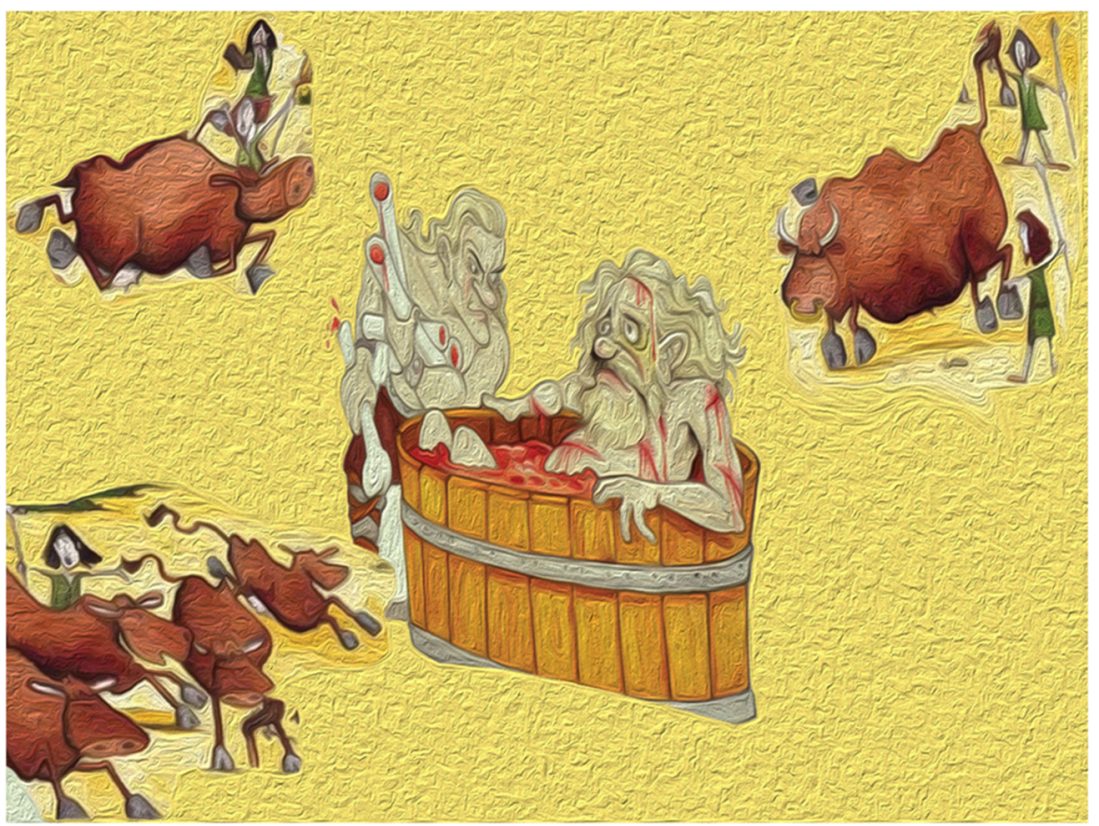

Fig. 11 First bone marrow transplantation; painting of the author (PH) according to the Irish artist painter James Cogan: Cethern is in the tub of marrow mash. Thereupon Fingin the prophetic leech asked of Cuchulain a vat of marrow wherewith to heal and to cure Cethern son of Fintan. Cuchulain proceeded to the camp and entrenchment of the men of Erin, and whatsoever he found of herds and flocks and droves there he took

extracts" [26]. The idea of removing damaged parts of the body and replacing them with healthy organs has been an aim shared by physicians since ancient times.

\section{Bone marrow as oral medication}

After the original mention of Brown-Séquard to propose marrow as a possible remedy, several authors reported employment: Macalister [27] recorded a favourable result of its use in one case of lymphadenoma (British Med. Jour., June, 1893.); away with him. And he made a marrow mash of their flesh and their bones and their skins; then, Cethern son of Fintan was placed in the marrow bath till the end of three days and three nights. And his flesh began to drink in the marrow bath about him. From The Ancient Irish Epic Tale Táin Bó Cúalnge, Author unknown, translated by Joseph Dunn. Gutenberg Project. 2005. EBook \#16464

Fraser [28], of Edinburgh, however, pressed the new remedy forcibly upon the attention of the medical world and this he did in a report of its curative effect in a case of progressive pernicious anaemia (British Med. Jour., April 7, 1894.). The clinical phenomena described were those of extreme anaemia, and the diagnosis was based on repeated blood examinations. That the utility of the agent is not limited to simple and easily curable cases of anaemia was strongly vouched for by W. G. Bigger [29] who claims to have cured by its influence a case of leucocythemia of six years' standing.
Fig. 12 Painting of the author (PH) according to the Irish artist painter James Cogan. The marrow bath entered in within his stabs and his cuts, his sores, and his many wounds. Thereafter, he arose from the marrow bath at the end of three days and three nights, and he slept a day and a night after taking in the marrow. From The Ancient Irish Epic Tale Táin Bó Cúalnge, Author unknown, translated by Joseph Dunn. Gutenberg Project. 2005. EBook \#16464

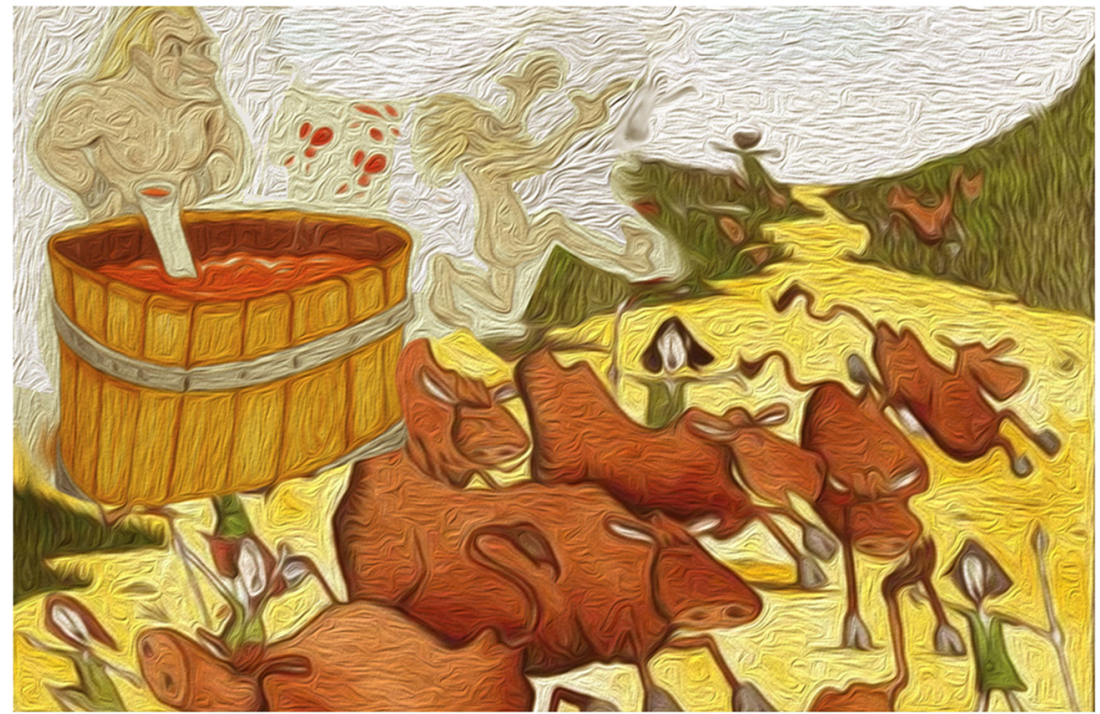




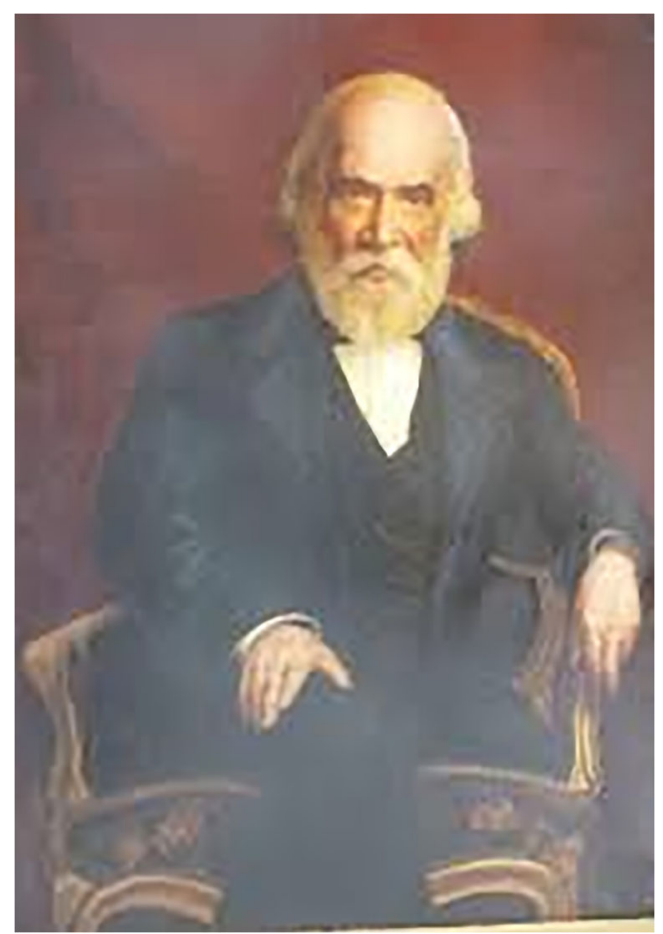

Fig. 13 Portrait of the French physician Charles-Edouard BrownSequard

One of the most satisfying contributions of the exact powers of the remedy, in various kinds of anaemia, is furnished by J. S. Billings, Jr. [30] "Bone marrow, then, and especially red

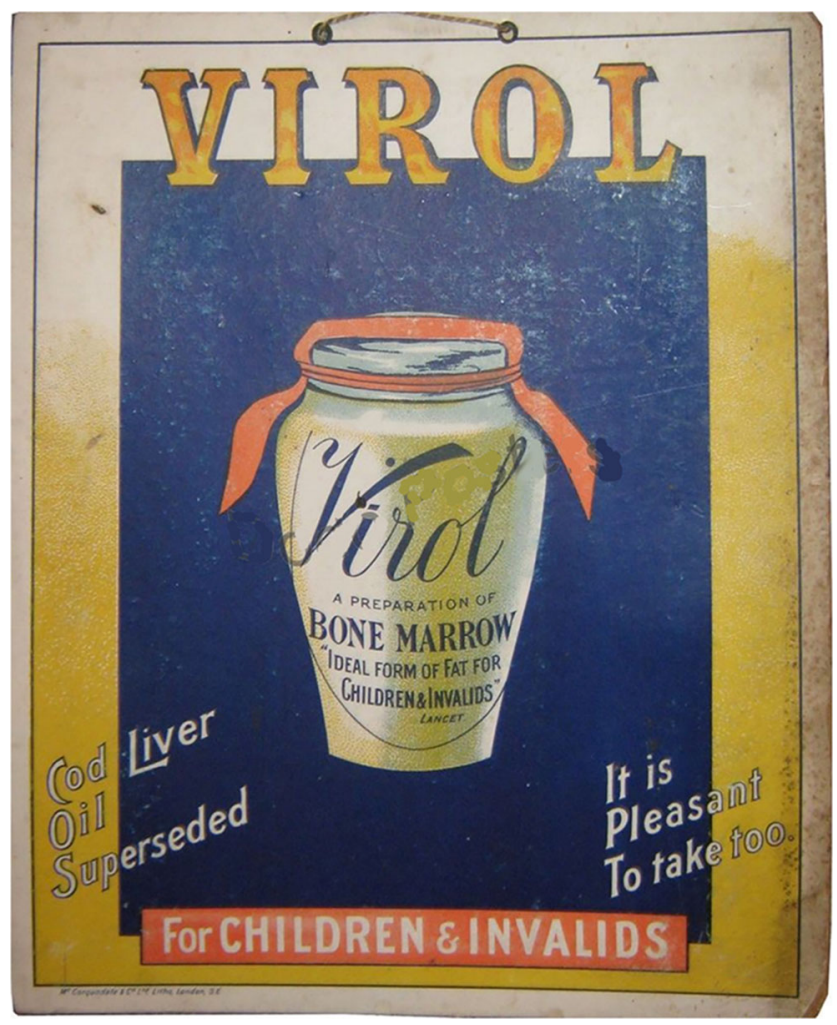

Fig. 14 Apothecary jar for bone marrow marrow, is certainly a readily assimilable organic compound of iron and is a valuable addition to the resources of the physician in cases of ordinary chlorosis and anaemia, in some cases of blood impoverishment of a more intractable kind. Whether it is anything more than an assimilable preparation of iron is not conclusively proved. The claims made for it in relation to the cure of pernicious anaemia, leukaemia and kindred disorders seem to be premature; for sufficient time had not elapsed in any case to warrant such a conclusion".

A. McL. Hamilton [31] also recorded an interesting series of observations. He tested both yellow and red marrow, but obtained better results from the red. In every case cited, the red corpuscles were counted by the Thoma-Zeiss apparatus and their haemoglobin value was estimated by the instruments of Fleischt, Growers and Henocque. Professor Hamilton shows that the multiplication of reds after profuse haemorrhage is approximately twice as rapid as the maximum rate hitherto recorded (20,000-30,000 daily per $\mathrm{mm}^{3}$ of blood) and that the total number of reds can be made to exceed the showing of normal blood $\left(5,000,000\right.$ per $\left.\mathrm{mm}^{3}\right)$ by fully $20 \%$ $\left(6,000,000\right.$ per $\left.\mathrm{mm}^{3}\right)$.

\section{Radium Girls, World War II, dragon's tail: effects of irradiation on bone marrow}

The origins of bone marrow transplantation (BMT) lie in the increasing presence of radiation present in everyday life at the turn of the twentieth century, culminating in the deadliest aspect of this technology, the atomic bomb. Several key fields within biomedical research, including radiobiology, cancer biology, immunology, and stem cell biology were significantly impacted, accelerated, and even originated as a result of World War II and the accompanying atomic age. Research spurned by this era led to the discovery and optimization of BMT.

\section{X-rays, glowing watches, trendy drinks, and Radium Girls: the first signs of a creeping demon}

Although this story is too complex for this history, we should recall the first description of the effects of radiation which dates from 1905. During the 1910s and 1920s, radioactive compounds were becoming increasingly common in the workplace. A higher incidence of leukaemia was observed in US radiologists as radioactive techniques and compounds, including X-rays, radium, and radon gas, become more common in modern medicine.

As regards radiation sickness, the Radium Girls [32] were female factory workers who contracted radiation poisoning from painting watch dials with self-luminous paint. The painting was done by women at three different United States Radium factories, and the term now applies to the women 
Fig. 15 Chairman address on the proposition of Brown-Sequard to treat leukemia with bone marrow as early as 1891

\section{CHAIRMAN'S ADDRESS.}

Address of the Chairman of the Section on the Practice of Medicine, delivered at the Forty-seventh innual Meeting of the American Medical Association. held at Atlanta, (ia., May 5-8. 1896.

BY WM. E. QUINE, M.D.

PROFESSOR OF THE PRACTICE OF MEDICINE IN THE COLLEGE OF PHYSICIANS AND SURGEONS OF CHICAGO AND PRESIDENT OF THE FACUITY.

THE REMEDIAL APPLICATION OF BONE MARROW.

For the original mention of bone marrow as a possible remedy we are indebted to Brown-Sequard and d'Arsonval who, in 1891, suggested its use in the treatment of leukemia and other diseases believed to be characterized by defective hemogenesis. A year and a half later Fillean reported its successful employment in the form of an extract, in the treatment of the anemia of debility and of tuberculosis; and Macalister recorded a favorable result of its use in one case of lymphadenoma. (British Med. Jour., June, 1893.) working at the facilities: one in Orange, $\mathrm{NJ}$, beginning around 1917; one in Ottawa, IL, beginning in the early 1920s; and a third facility in Waterbury, CT. Bolstering this correlation, women who worked in factories (Fig. 16) using radium paint were much more prone to develop oral, bone, and jaw cancers. Painters would lick their brushes to ensure a fine point and even paint their nails, face, and teeth to give them that trendy glow. Radium paint emits light and was used to paint watch and dials to highlight their numbers. Glowing was trendy in more than just watches in the 1920s; companies sold a variety of glowing tonics, medicines, and even radon-infused water for vigor. Now known as radio-luminescence, the emitted light was a result of the radioactive decay. Radioactive decay is the process by which an unstable atom becomes more stable by emitting various forms of energy, in this case, light energy. Many of the women later began to suffer from anaemia, tumours, bone fractures, and necrosis of the jaw, a condition now known as radium jaw. Unfortunately for these workers and trendy consumers, these first concentrated exposures to radioactive elements became the earliest recognized warnings for radiation sickness, cancer (Fig. 17), and death now associated with radiation.

\section{World War II, atomic bomb, and consequences on bone marrow}

The evolution of bone marrow transplants from mice to man and from World War II until today is a remarkable story
Fig. 16 Radium Girls. The first painter licks her brush to ensure a fine point

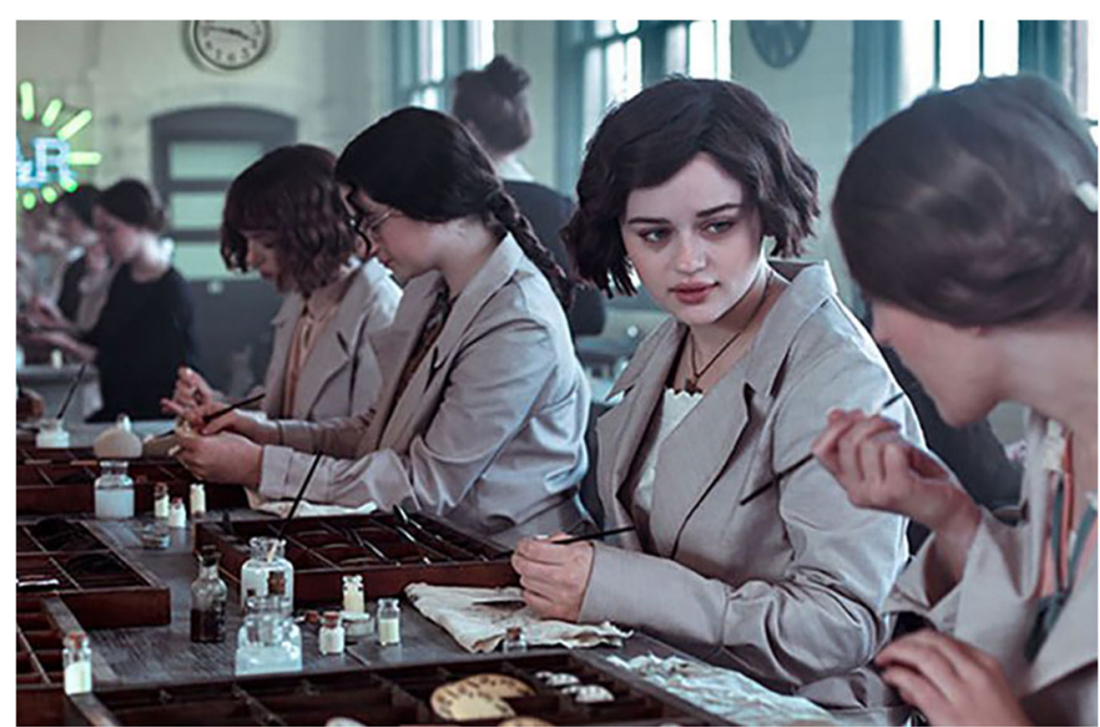




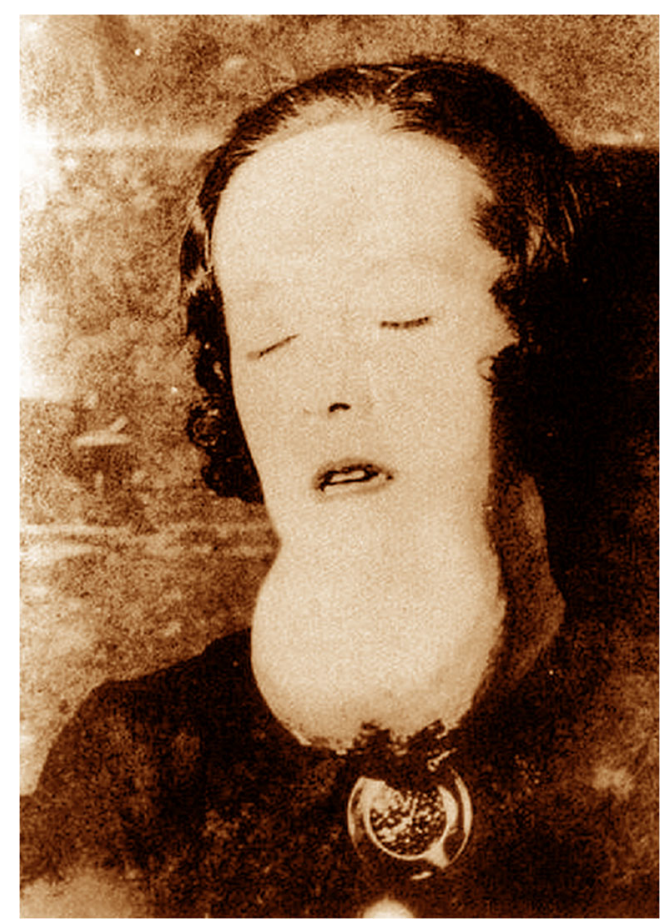

Fig. 17 A Radium Girl with radium-induced sarcoma of the jaw

illustrating the principle of unintended consequences. It shows how developing weapons of mass destruction paradoxically led to a technology which saves lives. Over one million bone marrow transplants have been done worldwide to save patients with leukaemia. World War II and the development of nuclear weapons and nuclear energy were paradoxically very important in the evolution of bone marrow transplantation. Albert Einstein signed a letter to President Roosevelt in 1939 (written by Leo Szilard) warning of German efforts to develop an atomic bomb. In response, the US Government recruited scientists at the National Institutes of Health and the University of Chicago (where Enrico Fermi had developed the first controlled nuclear chain reaction) to work on ways to counter the effects of radiation on humans, especially bone marrow failure. The development of the "atomic" bomb was the result of the Manhattan Project [33] and emphasis on the close relationship between ionizing radiation and bone marrow damage. Although the atomic bomb evolved from a war initiative, the discovery was to have major biological significance. The first detonation of a nuclear device in New Mexico in 1945 and the subsequent effects of the atomic bomb on the populations of Hiroshima and Nagasaki provoked great and urgent interest in the effects of irradiation on bone marrow.

\section{Tickling the dragon's tail accelerates the bone marrow knowledge}

Dr. Louis Hemplemann, who directed medical research for the Manhattan Project at Los Alamos, was the first to treat victims of an experiment called tickling the dragon's tail which resulted in a criticality (an uncontrolled fission reaction) in 1946. Nearly a year had passed since the bombs exploded over Hiroshima and Nagasaki. The world knew the power of atomic weapons; the Cold War was dawning. Yet, in Los Alamos, scientists were still "pushing uranium around with screwdrivers." On May 21, 1946, Louis Slotin (Fig. 18) suffered a fatal dose of radiation while he demonstrated the technique of critical assembly and associated studies and measurements to another scientist.

Critical assembly involves bringing two or more pieces of fissile material together to form a critical mass, the mass at which atomic chain reaction occurs. The technique, called "tickling the dragon's tail," allowed Slotin to calculate critical mass, which would be necessary to detonate in an atomic weapon. The method involved delicately screwing two hollow spheres of beryllium around a mass of fissionable material. Two 1-in. spacers between the upper hemisphere and the lower shell provided the only "safety" measure preventing inadvertent critical assembly. During a normal procedure, the spacers were removed to allow one edge of the upper hemisphere to rest on the lower shell while a screwdriver supported the other edge of the upper hemisphere. The operator would then lower the screwdriver bringing the remaining edges together.

Meanwhile, a Geiger counter would record the radioactivity as the operator brought the masses together. During Slotin's demonstration, something went terribly wrong. As he slowly allowed the latter edge to approach the lower shell, one hand held the screwdriver (Fig. 19) while the other hand was holding the upper shell with this thumb placed in an opening. At that time, the screwdriver apparently slipped and the upper shell fell into position around the fissionable material. A "blue glow" appeared; a heat wave moved through the room. "Slotin lunged forward and grabbed the two hemispheres with his bare hands, ripped them apart and took the full brunt of a nuclear detonation right in his stomach."

Slotin immediately understood what had happened. As a result of the accident, he died nine days later, his body decomposing from the massive dose of radiation. During the nine days before he died, he insisted that his physical state be continuously documented so that the effects of radiation could be used for scientific purposes. The tragic event of May 1946 foreshadowed many accidents in the Cold War decades to follow.

\section{Radiation chimera: from bone marrow transplants in the battlefield to leukaemia}

\section{The "mouse radiation chimera"}

One interesting approach which arose after this accident was to treat accident of irradiation and relates to doing bone 
Fig. 18 Louis Slotin (left) and Herbert Lehr with the Gadget bomb, July 13, 1945 (Los Alamos

National Laboratory photo)

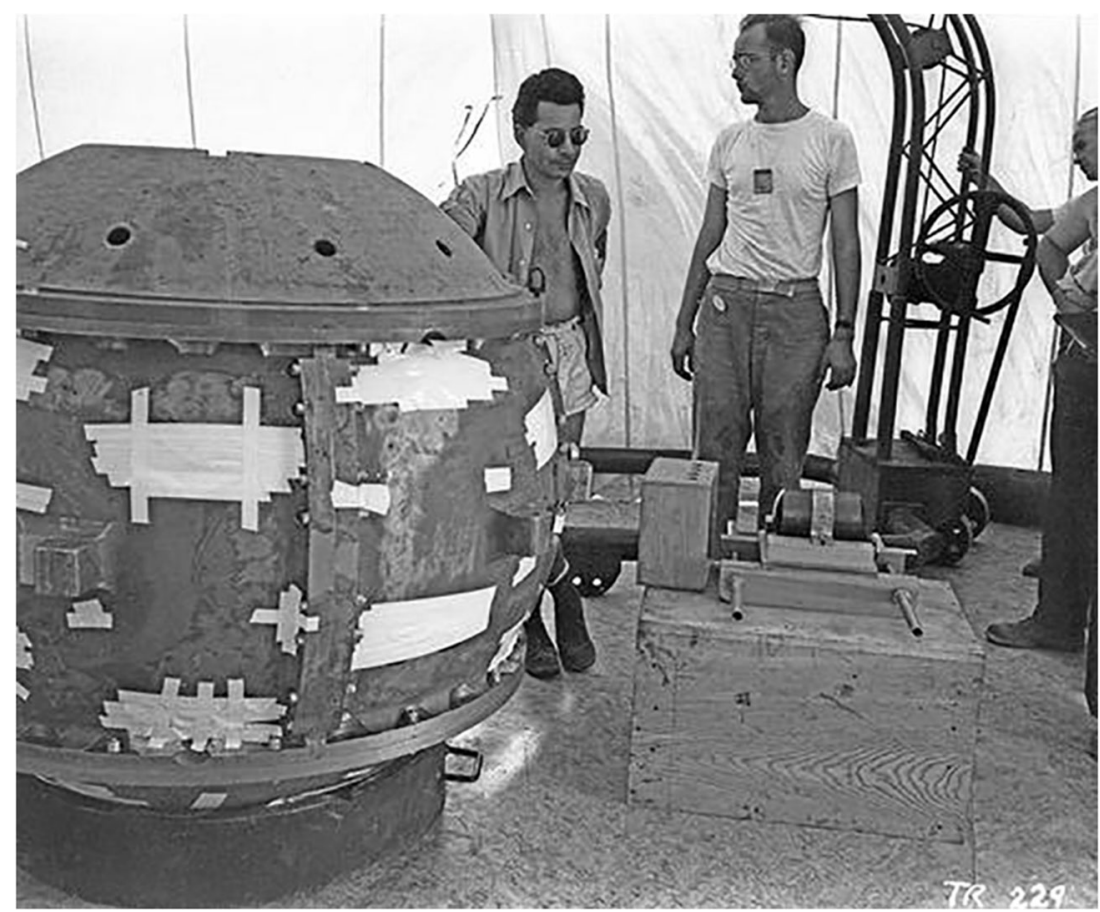

marrow transplants in the battlefield. The idea was that an enemy might use a tactical nuclear weapon; many soldiers would be irradiated and at risk of dying from bone marrow failure. Medics would roll up, extract some blood or bone marrow from a volunteer, and mix it with an aliquot of the radiation victim's blood. From a theoretical point of view, the donor cells would proliferate.

While studying the effects of lethal irradiation in mice, Jacobson [34] discovered in 1949 a protective effect of splenic shielding: the spleen in mice (Fig. 20) contains haemopoietic tissue. He went on to demonstrate a similar protective effect by shielding the femur in 1951. Two years later, Lorenz [35] showed that this protection could also be conferred by intravenous bone marrow infusion. At first, it was thought that the radiation protection was due to humoral elements in the syngeneic bone marrow. Over the next five years, however, a number of investigators demonstrated that, not only was the protection due to cellular elements, but that these donor cells
Fig. 19 Slotin and the screwdriver supporting the other edge of the upper hemisphere; interesting to see what the atomic research laboratory looked like in 1946

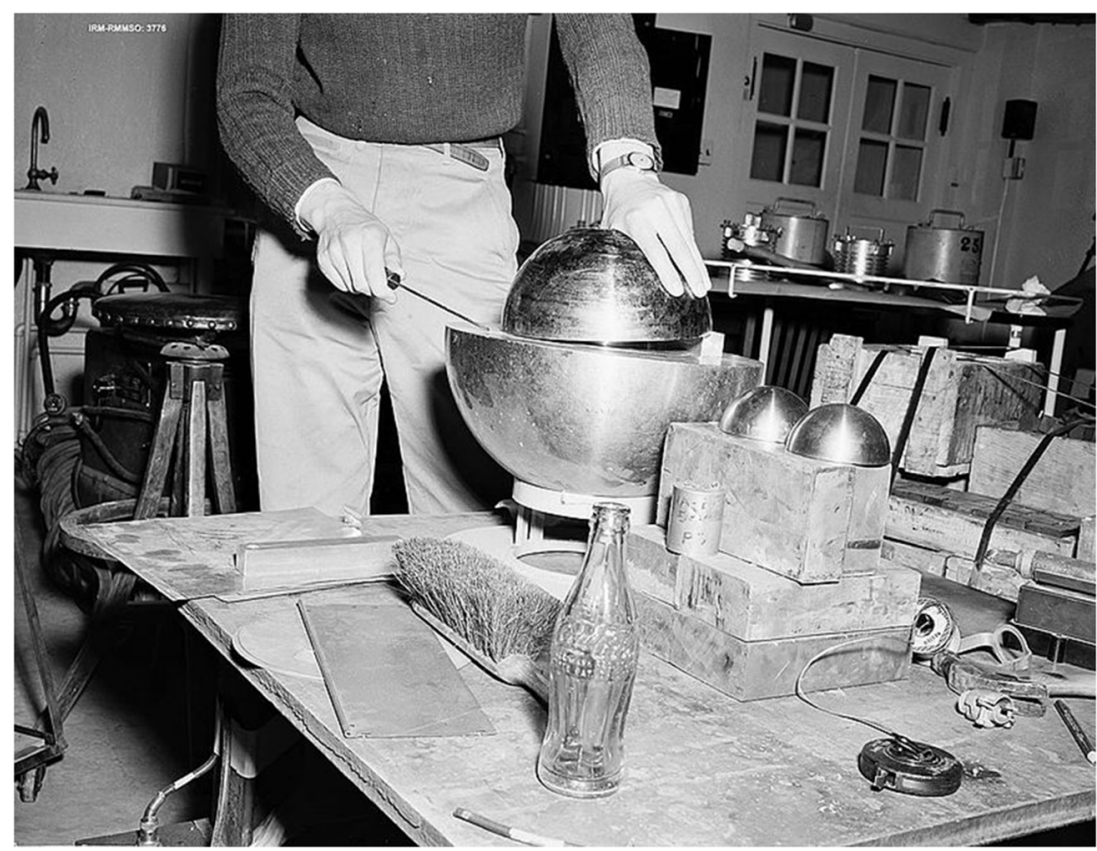


Jacobsen's radiation protection experiments
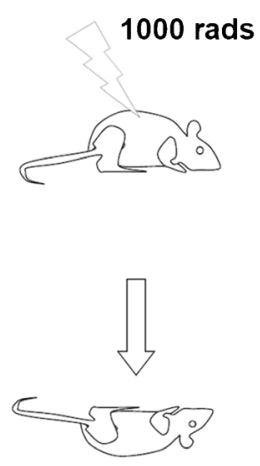

died

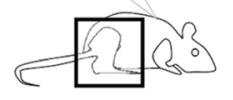

Shield hind limb

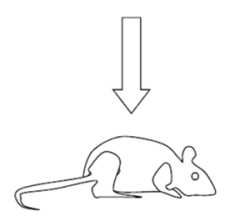

protected

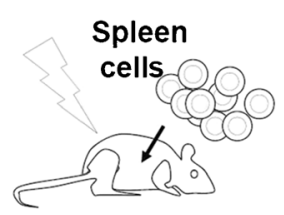

Inject spleen cells

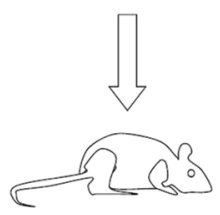

protected

Fig. 20 Jacobsen's radiation protection experiments

effectively repopulated the irradiated marrow. An animal whose hemopoietic system was derived from another animal was termed a "radiation chimera."

\section{The first "human radiation chimera" were performed before knowledge of stem cells}

In 1956, E. Donnell Thomas, recipient of the 1990 Nobel Prize (Fig. 21) performed to treat leukemia a bone marrow transplant between genetically identical twins. The first allogeneic HSCT (leading to its current status) was pioneered by E. Donnall Thomas [36] and reported in the New England Journal of Medicine on September 12, 1957. In this study, six patients were treated with radiation and chemotherapy and then received intravenous infusion of marrow from a normal donor. Only two patients engrafted, and all died by 100 days post the transplantation. At that time, little was known about histocompatibility antigens, and no one tried to

match donors and recipients. Interestingly, the first bone marrow transplantations were performed before the discovery of stem cells [37] in 1963 by Becker, McCulloch, and Till who conducted experiments. After injecting bone marrow cells into irradiated mice, nodules developed in proportion to the number of bone marrow cells injected, and they concluded that each nodule arose from a single marrow cell.

In 1958, a radiation accident occurred in Vinca, Yugoslavia, and five physicists developed radiation-induced aplasia. Georges Mathé, Henri Jammet, and Leon Schwatzenberg transplanted allogenic bone marrow [38] from several relatives to each of the workers exposed to ionizing radiations from a nuclear reactor accident in Vinca, Yugoslavia. Their reason for choosing several related donors was the notion that the best bone marrow would win. At this period, URSS was not able to treat these patients, and of course, Yugoslavia did not want help from the USA, which explains the arrival of these patients in France. Although one died, Mathé (Fig. 22) described the successful infusion of allogeneic bone marrow into the remaining five who were able to survive and subsequently demonstrated transient engraftment using red-cell antigen studies. Eventually, it is presumed autologous hemopoietic recovery supervened, but it is likely that the allogeneic marrow afforded a temporary protective effect.

For the little story, Georges Mathé (1922-2010) some years later had a fracture and a nonunion of the lower tibia; as his haematologist friends recommended him to the author for another orthopaedic advice, he was treated by the author by an injection of concentrate bone marrow in 1995; Mathé was surprised and interested by the fact that an orthopedist surgeon could use bone marrow at this period. But he was not surprised that it worked when he got union. His case is incidentally one of the patients published by the author [39] in
Fig. 21 Dr. Thomas (left) received the Nobel Prize in Physiology or Medicine from King Carl Gustaf of Sweden in 1990

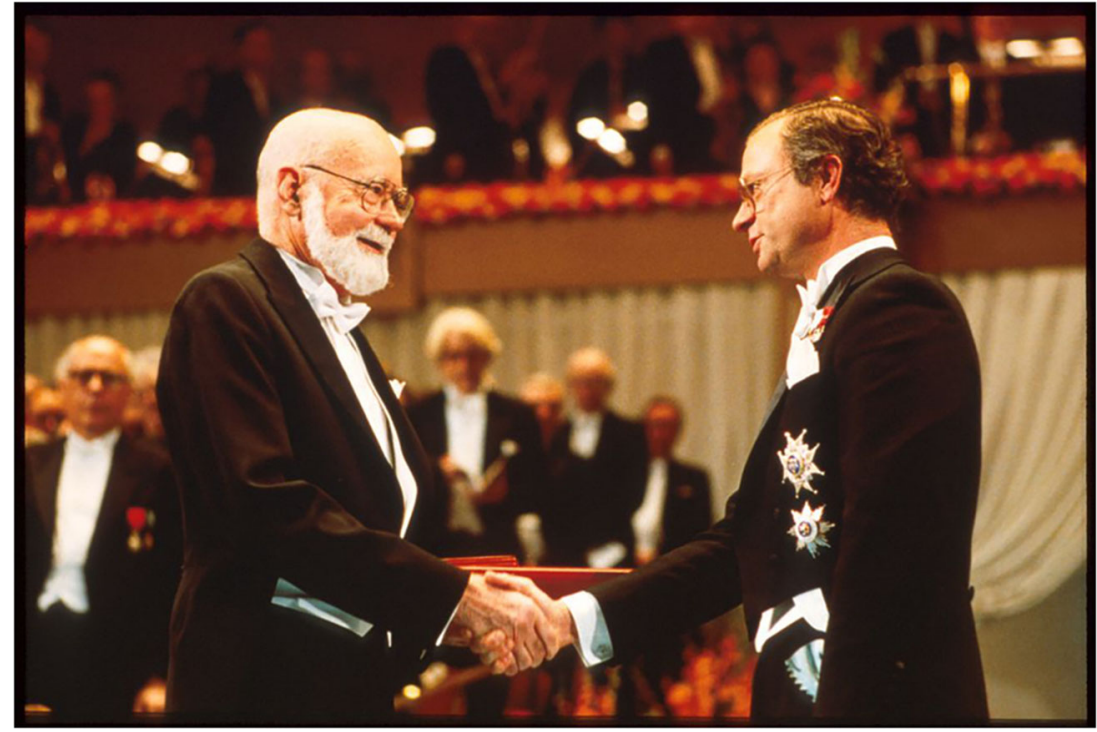




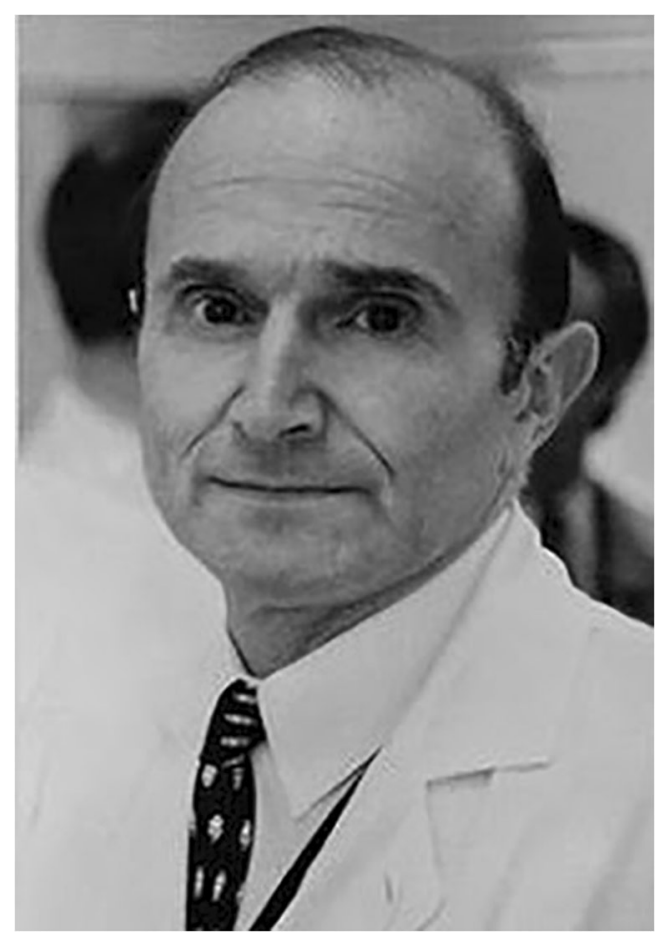

Fig. 22 Photograph of Georges Mathé

the American Journal of Bone and Joint Surgery; this gave the opportunity for the author, as early as in 1995 , to discuss with him about the future of bone marrow transplant in orthopaedic surgery and to get some advice about mesenchymal stem cells (MSCs). One of the parts of discussion between Mathé and the author was about the composition of bone marrow of patients after successful engraftment of donor-derived haematopoiesis. Some of these patients had hip osteonecrosis after allogenic transplantation for leukaemia. These patients are chimera from a haematologic point of view, but at this period, it was not well known whether MSCs remained of host origin or were from haematologic origin. For professor Mathé, even years after bone marrow transplantation, and despite successful engraftment of donor-derived haematopoiesis, MSCs were in general of host origin which is now confirmed [40]. He gave as authorized and useful advice to the author to treat these patients with bone marrow aspiration of their iliac crest rather than using allogenic MSCs coming from the donor.

\section{Discovery of stem cells}

The development of cell biology coincides with the advance of microscopes in the nineteenth century. It was finally possible to directly observe the various blood cell types and to witness their proliferation and differentiation. On the basis of his observations, the German pathologist Franz Ernst Christian Neumann (1834-1918) concluded that the site of blood formation was the bone marrow [41]. He also proposed the pioneer theory in which one cell might be at the origin of all blood cell lineages. The Russian scientist Alexander A. Maximow (1874-1928) also developed and introduced in 1909 the theory of a common cell for the complete bloodbuilding system or haematopoiesis, as well as the idea of a microenvironmental niche for these cells within the bone marrow [42]. The concept of haematopoietic stem cells (HSCs), although very controversial at the time, was born and has led to the beginning of stem cell research.

Becker, McCulloch, and Till [37] gave the first experimental proof of the haematologic stem cell theory by performing the transplantation of bone marrow cells into irradiated mice. These cells gave rise to myeloid multilineage colonies in the spleen of transplanted animals, the number of colonies being proportional to the number of injected cells. Such experiments demonstrated the multilineage potential of single bone marrow cells (so-called CFU-S, colony-forming unit in the spleen).

In the 1960s, Owen and Friedenstein [43] discovered multipotent conjunctive progenitors by cultivating bone marrow of rabbits at low density in a liquid medium with serum; this resulted in the description of colonies with plasticadherent cells. These colonies were derived from one cell type in the bone stromal marrow and they were named colonyforming unit-fibroblasts. Bone marrow stromal cells (BMSCs) were named "mesenchymal stem cells" (MSCs) in the 1990s [44].

\section{Mesenchymal stem cells: from “lab manufacturing" to bioreactors}

\section{From the lab to culture}

The heterogeneity of MSC isolation, culture methods, and the consequent difficulty to compare the results obtained in clinical and nonclinical studies, conducted between 1990 and 2000, encouraged the International Society of Cellular Therapy (ISCT) to propose criteria for MSC classification in 2006. According to the ISCT definition, "multipotent mesenchymal stromal cells" should be adherent to plastic, positive for CD105, CD73, and CD90 and negative for the expression of CD45, CD34, CD14 or CD11b, CD79 or CD19, and human leukocyte antigen class II, and should also be able to differentiate in vitro into osteoblasts, adipocytes, and chondroblasts.

\section{Bone marrow centrifugation}

Lawrence Berman (1947) was the first to perform bone marrow centrifugation for diagnosis; $1 \mathrm{~cm}^{3}$ of heparinized marrow suspension was placed in a Wintrobe haematocrit tube and then centrifuged. At the end of the period of centrifugation 
[45], usually about five minutes, the specimen will be separated into three or four layers, namely, fat (when present), plasma, nucleated cells, and erythrocytes. The heights of the various layers were recorded, and the data obtained by centrifugation were used for diagnosis and interpretation of marrow lesions. The fat was discarded and most of the plasma removed. The nucleated cell layer of the concentrate of marrow cells was easier to examine.

The rationale to propose a bone marrow concentrate to treat orthopaedic disease was proposed by the author [46] as early as 1985. In crude BMA injection, the concentrations of the cells are lower than the concentration of the cells that are present in the bone marrow cavity, due to dilution by blood during aspiration. However, based on centrifugation, the number of MSC might be increased. A bone marrow concentrate is a small volume of fluid containing a high concentration of cells extracted from the bone marrow, such as high yields of MSCs (can be measured as CFU-Fs). Furthermore, the presence of bone marrow cells is completed by the presence of increased levels of growth factors, cytokines like IL-8, and interleukin-1RA.

\section{MSC manufacturing: from conventional cultures to bioreactors}

Despite the vast potential, the MSC therapeutic use is still limited by the need for in vitro expansion due to the low frequency of these cells in the tissues of origin (frequency in the bone marrow, e.g., is $0.001-0.01 \%$ ) [47] and by the high doses required for an infusion $(1-100 \times 106$ cells $/ \mathrm{kg}$ of patient) in some treatments. Although MSCs are often used in an allogeneic scenario, their autologous use can also be employed. This choice, scale-out versus scale-up, shall have a great impact on the manufacturing process production and, consequently, on the cost. For MSC autologous use, as a lower cell quantity is required, the scale-out approach can be followed, increasing the number of planar culture systems (multiple flasks in cell factories, preferably fully automated). Considering the MSC allogeneic use, it is possible to produce a large number of cells in bioreactor systems (scale-up approach) and to create a robust cell bank to supply cells for all therapies [48].

A large number of evidence have demonstrated that the 2D system compromises the potency of MSC. Additionally, monolayer culture flasks are considered as "open system," because their subculture (inoculation, medium exchange, and cell harvesting) is carried out in laminar flow cabinets by direct operator manipulation [49]. Although automation and robotics could minimize the disadvantages listed above, this technology is not amenable to scale-up when lots, higher than 100 billion, of cells are required [50]. Although it still represents an open system and intensive labour, it offers a greater surface area for growth per vessel and reduces the medium requirement compared with T-flasks. Roller bottles have been used for MSC tissue engineering applications and expansion in accordance with good manufacturing practices (GMP), and quality standards requires a fully closed, controllable, and scalable culture system [51]. Bioreactor-based cell expansion meets these requirements. The bioreactor can be defined as a culture system in which there is a proper monitoring and control of culture variables such as $\mathrm{pH}$, temperature, oxygen, and carbon dioxide concentration for the maintenance of a homogeneous physicochemical environment for the cells, as well as the support for cell adhesion (adherent cells) when needed. Several bioreactor types are now available for MSC expansion.

\section{Bone marrow transplantation in orthopaedic diseases}

\section{Systemic intravenous allogenic MSC transplantation in orthopedic diseases}

The first reports of MSC clinical use occurred between 1995 and 2000 for the treatment of patients with osteogenesis imperfecta [52-54]. The results of these first clinical studies demonstrated the MSC therapeutic potential as well as the feasibility and safety of such treatments. At that time, it was assumed that MSCs could engraft and differentiate into multiple tissues to replace damaged cells [54], as engraftment was obtained with haematologic stem cells.

Bone marrow mesenchymal cells can differentiate to a variety of tissues including bone, cartilage, muscle, and fat. Thus, in principle, bone marrow transplantation (BMT) could provide effective therapy for disorders that involve cells derived from mesenchymal precursors. One attractive candidate is osteogenesis imperfecta (OI) or "brittle bone disease," a genetic disorder caused by defects in type I collagen, the major structural protein of the extracellular matrix of bone. Patients with severe OI have numerous painful fractures, progressive deformities of the limbs and spine, retarded bone growth, and short stature. There is no cure for OI, and only one class of drugs, the bisphosphonates, which can reduce or prevent bone resorption, appears to have therapeutic potential. Ideally, therapy for OI should be directed toward improving bone strength by improving the structural integrity of collagen and thereby the quality of the bone.

After ex vivo expansion, Horwitz et al. could transplant a total number of 1 to $5 \times 106$ MSCs per kilogram recipient body weight in a series of six patients with osteogenesis imperfecta. In five of them, engraftment of MSCs took place, proving that, at least when applying ex vivo-expanded MSC, donor-derived MSCs can settle in the bone marrow [55]. Horwitz et al. detected skin fibroblasts of donor origin after allogeneic MSC transplantation in children with osteogenesis imperfecta. 


\section{Systemic intravenous stem cell transplantation in orthopaedic complications of general diseases}

Another unique advantage of MSCs is their immuneprivileged characteristic which is partially due to absence of expression of histocompatibility complex (MHC) II antigens that cause immune rejection. The effect of allogenic stem cells on osteonecrosis [56] was observed in patients with osteonecrosis secondary to sickle cell disease. The marrow was infused intravenously for one-half hour, beginning 48 hours after the last infusion of cyclophosphamide. The dose of nucleated marrow cells that was infused was 200 million per kilogram of body weight. The patient had total repair of his osteonecrosis.

Over the last ten years, advances in bone marrow transplantation have revolved around four main areas. First has been the expansion of transplants to include nonmalignant diseases, with success in patients with thalassaemia, sickle cell disease, and inherited metabolic diseases.

\section{Local bone marrow MSC implantation in orthopaedic surgery}

Joint osteonecrosis The rationale for cell therapy in osteonecrosis, as well as the different descriptions of the technique of implantation of osteogenic progenitor cells, began as research program in 1985 with the author [57]. The occurrence of ONFH may be associated with insufficient MSCs, or functional defects of MSCs, and the factors that affect the proliferation and differentiation of MSCs, such as hormones and alcohol, led to disorder of osteoblast metabolism and necrosis of the femoral head. A decrease in the number of MSCs was found outside of the area of ONFH in patients with corticosteroid-induced ONFH. This reduction was in part related to the absence of MSCs in the osteonecrotic lesion itself and associated with a global reduction in MSCs in the proximal part of the femur. As a consequence, cell therapy was proposed in association with core decompression, and after animal experiments, the first patient was operated on in 1987 with cell therapy for hip osteonecrosis in the Henri Mondor Hospital, University of Paris and first results were reported in English literature in 2002.

Cartilage lesions The current literature demonstrates the potential benefits of utilizing bone marrow aspiration for the repair of cartilage injury in the clinical setting. Significant clinical improvement in functional scores was demonstrated in the treatment of full thickness cartilage injury, posttraumatic osteoarthritis, and osteochondral lesions. Improved clinical and histologic results were reported for microfracture in the treatment of full-thickness chondral lesions. On MRI, groups treated with bone marrow aspiration (BMA) demonstrated superior cartilage ingrowth with $\mathrm{T} 2$ values closer to that of superficial hyaline cartilage when compared to either a control scaffold or MACI alone. Gobbi et al. [58] compared with microfracture with BMA in the treatment of OCLs and found that microfracture resulted in $65 \%$ normal IKDC at two years with decline to $27 \%$ at five years vs $100 \%$ normal at two years and no decline at five years for patients treated with BMA. These positive results were found when evaluating BMA in the treatment of knee osteoarthritis [59-61].

Tendon lesions One study evaluated open Achilles tendon repair augmented with BMA and reported excellent functional outcomes, early mobilization, normal range of motion, and no re-ruptures at a mean follow-up of 29.7 months [62]. One study evaluated the use of BMA during rotator cuff repair and reported enhanced healing rates, improved quality of the repair surface on ultrasound and MRI, and a decreased risk of re-rupture when compared to the control group [63].

\section{Is the COVID-19 virus in bone marrow?}

The first human cases of COVID-19 were first reported at the end of December 2019 from Wuhan, China. After nine months of the pandemic, 4 million of patients contaminated, and more than 300,000 deaths, it is difficult to answer this simple question. For haematologists, this question is important since access to a stem cell donor might be restricted due to the donor becoming infected. COVID-19 have been detected in blood, although at this moment there have not been any reports of transmission from donor to recipient either in transfusion of blood products or cellular therapies [64]. In case of diagnosis of COVID-19, a bone marrow donor must be excluded from donation. But at this time, it is not possible to give recommendations when such an individual can be cleared for donation. In terms of pathogenesis, the COVID-19 recognizes the angiotensin converting enzyme 2 receptor (ACE2) by its spike protein. ACE2 is widely expressed in human tissues, including haematopoietic stem [65]. ACE2 stimulates mobilization of progenitor cells from the bone marrow.

For the orthopaedic surgeon, however, it is unclear whether MSCs could be infected by COVID-19. Mesenchymal stem cells (MSCs) have been described to have strong immunomodulatory properties. These cells have capacity to migrate to inflammatory sites, having anti-inflammatory and antifibrotic effects. Thus, MSCs could offer a new therapeutic approach. Moreover, their regenerative potential in particular, in vascular dysfunction of COVID-19, could be a good point. A recent paper suggests that human MSCs are resistant to COVID-19 infection [66]. For the orthopedist surgeon, using allografts in the COVID-19 period is a problem: we have no idea of how long the virus could survive in bone marrow if it is present. 


\section{Conclusion}

The last 50 years have seen the emergence of bone marrow transplantation in orthopaedic surgery as a potential treatment for some diseases. The concept of bone marrow transplantation now includes aspiration, bone marrow concentration, in vitro expansion, tissue engineering, and bioreactors. Despite the opportunities presented by this wealth of possibility, there remain challenges. The transition from monolayerbased expansion to bioprocess using bioreactors has been experienced extensively by the pharmaceutical industry for viral vaccines and recombinant proteins. The production of cellbased products had to consider the peculiarities of this new type of product, mainly referring to post-expansion cellular safety and functionality. Due to their primary nature, MSCs cannot be cultivated indefinitely, due to their senescence and eventual loss of important functional properties. The use of MSCs with less than 20 population doublings has been suggested for clinical applications to ensure safety and efficacy. Another remaining challenge is related to the complexity of cell-based product production process and, consequently, the high cost of goods. As a result, the search for economically viable production processes will be critical if cell therapy products are intended to achieve the commercial manufacturing success of biopharmaceutical cell or some cell production.

\section{Compliance with ethical standards}

Conflict of interest The author declares that he has no conflict of interest.

Ethical approval This is a history paper.

\section{References}

1. Hernigou P (2020) The history of bone marrow in orthopaedic surgery (part I trauma): trepanning, bone marrow injection in damage control resuscitation, and bone marrow aspiration to heal fractures. Int Orthop 44(4):795-808. https://doi.org/10.1007/s00264020-04506-Z

2. Carroll L (1895) Alice's Adventures in Wonderland; publisher Mac Millan

3. Sanchez S, Tafforeau P, Ahlberg PE (2014) The humerus of Eusthenopteron: a puzzling organization presaging the establishment of tetrapod limb bone marrow. Proc R Soc B Biol Sci 281(1782):20140299. https://doi.org/10.1098/rspb.2014.0299

4. Rothschild BM, Storrs GW (2003) Decompression syndrome in plesiosaurs (Sauropterygia: Reptilia). J Vertebr Paleontol 23:324 328

5. Bornstein, Plate (1911-1912) Uber chronische Gelenkvanderungen, enstanden durch presslufterkrankung; Fortsch. Rontgenstr 18: 197209

6. Bassoe P (1913) The late manifestations of compressed-air disease. Am J Med Sci N Ser 145:526-542

7. Davidson JK (1976) Dysbaric osteonecrosis. In: Davidson JK (ed) Aseptic necrosis of bone. Excerpta Medica, Amsterdam, pp 147-212
8. Kawashima M, Torisu T, Hayashi K, Kitano M (1978) Pathological review of osteonecrosis in divers. Clin Orthop 130:107-117

9. Torti SR, Billinger M, SchwerzmannM VR, Zbinden R, Windecker S, Seiler C (2004) Risk of decompression illness among 230 divers in relation to the presence and size of patent foramen ovale. Eur Heart J 25:1014-1020

10. Fazeli PK, Horowitz MC, MacDougald OA, Scheller EL, Rodeheffer MS, Rosen CJ, Klibanski A (2013) Marrow fat and bone-new perspectives. J Clin Endocrinol Metab 98:935-945

11. Muir R, Drummond WB (1893) J Anat Physiol 28:125-141

12. Scheller EL, Cawthorn WP, Burr AA, Horowitz MC, MacDougald OA (2016) Marrow adipose tissue: trimming the fat. Trends Endocrinol Metab 27:392-403

13. Kricun ME (1985) Red-yellow marrow conversion: its effect on the location of some solitary bone lesions. Skelet Radiol 14:10-19

14. Zakaria E, Shafrir E (1967) Yellow bone marrow as adipose tissue. Proc Soc Exp Biol Med 124:1265-1268

15. Tavassoli M (1976) Marrow adipose cells. Histochemical identification of labile and stable components. Arch Pathol Lab Med 100: $16-18$

16. Scheller EL, Rosen CJ (2014) What's the matter with MAT? Marrow adipose tissue, metabolism, and skeletal health. Ann N Y Acad Sci 1311:14-30

17. Scheller EL, Doucette CR, Learman BS, Cawthorn WP, Khandaker S, Schell B, Wu B, Ding SY, Bredella MA, Fazeli PK (2015) Region-specific variation in the properties of skeletal adipocytes reveals regulated and constitutive marrow adipose tissues. Nat Commun 6:7808

18. Devlin MJ (2011) Why does starvation make bones fat? Am J Hum Biol 23:577-585

19. Hernigou J, Koulischer S, Maes R (2017) Bilateral simultaneous femoral neck stress fracture despite clinical recovery from anorexia nervosa: a case report. JBJS Case Connect 7(1):e12. https://doi.org/ 10.2106/JBJS.CC.16.00047

20. Vande Berg BC, Malghem J, Lecouvet FE, Devogelaer JP, Maldague B, Houssiau FA (1999) Fat conversion of femoral marrow in glucocorticoid-treated patients: a cross-sectional and longitudinal study with magnetic resonance imaging. Arthritis Rheum 42:1405-1411

21. Hernigou P, Dubory A, Homma Y, Guissou I, Flouzat Lachaniette $\mathrm{CH}$, Chevallier N, Rouard H (2018) Cell therapy versus simultaneous contralateral decompression in symptomatic corticosteroid osteonecrosis: a thirty-year follow-up prospective randomized study of one hundred and twenty five adult patients. Int Orthop 42(7):1639-1649. https://doi.org/10.1007/s00264-018-3941-8

22. Gaucher PCE (1882) De l'epithelioma primitif de la rate, hypertrophie idiopathique de la rate sans leucemie [Primary epithelioma of the spleen, idiopathic hypertrophy of the spleen without leukemia] (academic thesis) (in French). Paris, France

23. Gale RP, McCann S (2017) A brief history of hematopoietic cell transplantation. Edited by Hillard M. Lazarus, in association with Syed Ali Abutalib. Cambridge University Press. https://doi.org/10. 1017/9781316335727.002

24. An Tain Bo Cuailnge (2005) Translated by Joseph Dunn. Project Gutenberg. Ebooks\#16464

25. Brown-Séquard CE (1893) On a new therapeutic method consisting in the use of organic liquids extracted from glands and other organs. Br Med J 1(1693): 1212-1214

26. Quine WE (1896) Chairman's address. JAMA 21:1012. https://doi. org/10.1001/jama.1896.02430730014001c

27. Macalister J (1893) Br Med J

28. Fraser P (1894) Br Med J

29. Bigge WG (1894) London Lancet, ii

30. Billings JS Jr (1894) Johns Hopkins Hospital Bulletin, v

31. Mc L, Hamilton A (1895) N Y Med J. lxi 
32. Moore K (2017). The Radium Girls, the dark story of America's shining women. Sourcebooks, Inc. ISBN 978-1492649366

33. Gosling FG (1994) The Manhattan Project: making the atomic bomb. United States Department of Energy, History Division, Washington, DC OCLC 637052193

34. Jacobson LO, Simmons EL, Marks EK et al (1951) Recovery from radiation injury. Science 113:510-511

35. Lorenz E, Uphoff D (1950). RCUT, C,C, Congdon Collection/ MS838 Box 2, Folder 4

36. Thomas ED, Lochte HL, Lu WC, Ferrebee JW (1957) Intravenous infusion of bone marrow in patients receiving radiation and chemotherapy. N Engl J Med 257:491-496

37. Becker A, Mcculloch E, Till J (1963) Cytological demonstration of the clonal nature of spleen colonies derived from transplanted mouse marrow cells. Nature 197:452-454

38. Mathé G, Bernard J, Schwartzenberg L (1959) Essai de traitement de sujets atteints - de leucemie aigue en remission per irradiation totale suivie de transfusion de moelle osseus homologue. Revue Francaise D'Etudes Clinique et Biologiques 4:871-875

39. Hernigou P, Poignard A, Beaujean F, Rouard H (2005) Percutaneous autologous bone-marrow grafting for nonunions. Influence of the number and concentration of progenitor cells. $\mathrm{J}$ Bone Joint Surg Am 87(7):1430-1437. https://doi.org/10.2106/ JBJS.D.02215

40. Rieger K, Marinets O, Fietz T, Körper S, Sommer D, Mücke C, Reufi B, Blau WI, Thiel E, Knauf WU (2005) Mesenchymal stem cells remain of host origin even a long time after allogeneic peripheral blood stem cell or bone marrow transplantation. Exp Hematol 33(5):605-611. https://doi.org/10.1016/j.exphem.2005.02.004

41. Mazzarello P (1999) A unifying concept: the history of cell theory. Nat Cell Biol 1:E13-E15

42. Maximow AA (1909) Untersuchungen uber blut und bindegewebe 1. Die fruhesten entwicklungsstadien der blut- und bindegewebszellan bein saugetierembryo, bis zum anfang der blutbilding unden leber. Arch Mikrosk Anat 73:444-561

43. Owen M, Friedenstein AJ (1988) Stromal stem cells:marrow-derived osteogenic precursors. CIBA Found Symp 136:42-60

44. Caplan AI (1991) Mesenchymal stem cells. J Orthop Res 9:641650

45. Berman L, Axelrod AR (1947) Evaluation of volumetric data obtained by centrifugation of aspirated sternal marrow of adults. I. Estimation of relative fat content. Am. J. Clin. Path., 17: 551556,. II. Estimation of cellularity of sternal marrow. Am J Clin Pathol 17:557-560

46. Hernigou P, Guerin G, Homma Y, Dubory A, Chevallier N, Rouard H, Flouzat Lachaniette CH (2018) History of concentrated or expanded mesenchymal stem cells for hip osteonecrosis: is there a target number for osteonecrosis repair? Int Orthop 42(7):17391745. https://doi.org/10.1007/s00264-018-4000-1

47. Pittenger MF, Mackay AM, Beck SC (1999) Multilineage potential of adult human mesenchymal stem cells. Science 284(5411):143147

48. dos Santos FF, Andrade PZ, da Silva CL, Cabral JMS (2013) Bioreactor design for clinical-grade expansion of stem cells. Biotechnol J 8(6):644-654

49. Sharma S, Raju R, Sui S, Hu WS (2011) Stem cell culture engineering - process scale up and beyond. Biotechnol J 6(11):13171329

50. Rowley J, Abraham E, Campbell A, Brandwein H, Oh S (2012) Meeting lot-size challenges of manufacturing adherent cells for therapy. Bioprocess International 10(3):15-22

51. Jung S, Panchalingam KM, Wuerth RD, Rosenberg L, Behie LA (2012) Large-scale production of human mesenchymal stem cells for clinical applications. Biotechnol Appl Biochem 59(2):106-120

52. Lazarus HM, Haynesworth SE, Gerson SL, Rosenthal NS, Caplan AI (1995) Ex vivo expansion and subsequent infusion of human bone marrow-derived stromal progenitor cells (mesenchymal progenitor cells): implications for therapeutic use. Bone Marrow Transplant 16(4):557-564

53. Horwitz EM, Prockop DJ, Fitzpatrick LA et al (1999) Transplantability and therapeutic effects of bone marrow-derived mesenchymal cells in children with osteogenesis imperfecta. Nat Med 5(3):309-313

54. Prockop DJ (2017) The exciting prospects of new therapies with mesenchymal stromal cells. Cytotherapy 19(1):1-8

55. Squillaro T, Peluso G, Galderisi U (2016) Clinical trials with mesenchymal stem cells: an update. Cell Transplant 25(5):829-848

56. Hernigou P, Bernaudin F, Reinert P, Kuentz M, Vernant JP (1997) Bone-marrow transplantation in sickle-cell disease. Effect on osteonecrosis: a case report with a four-year follow-up. J Bone Joint Surg Am 79(11):1726-1730. https://doi.org/10.2106/ 00004623-199711000-00015

57. Hernigou P, Trousselier M, Roubineau F, Bouthors C, Chevallier N, Rouard H, Flouzat-Lachaniette CH (2016) Stem cell therapy for the treatment of hip osteonecrosis: a 30-year review of progress. Clin Orthop Surg 8(1):1-8. https://doi.org/10.4055/cios.2016.8.1.1

58. Gobbi A, Whyte GP (2016) One-stage cartilage repair using a hyaluronic acid-based scaffold with activated bone marrowderived mesenchymal stem cells compared with microfracture: five-year follow-up. Am J Sports Med 44:2846-2854

59. Centeno CJ, Al-Sayegh H, Bashir J, Goodyear S, Freeman MD (2015) A dose response analysis of a specific bone marrow concentrate treatment protocol for knee osteoarthritis. BMC Musculoskelet Disord 16:258. https://doi.org/10.1186/s12891-015-0714-Z

60. Hernigou P, Delambre J, Quiennec S, Poignard A (2020) Human bone marrow mesenchymal stem cell injection in subchondral lesions of knee osteoarthritis: a prospective randomized study versus contralateral arthroplasty at a mean fifteen year follow-up. Int Orthop. https://doi.org/10.1007/s00264-020-04571-4

61. Hernigou P, Bouthors C, Bastard C, Flouzat Lachaniette $\mathrm{CH}$, Rouard H, Dubory A (2020) Subchondral bone or intra-articular injection of bone marrow concentrate mesenchymal stem cells in bilateral knee osteoarthritis: what better postpone knee arthroplasty at fifteen years? A randomized study. Int Orthop. https://doi.org/10. 1007/s00264-020-04687-7

62. Stein BE, Stroh DA, Schon LC (2015) Outcomes of acute Achilles tendon rupture repair with bone marrow aspirate concentrate augmentation. Int Orthop 39:901-905. https://doi.org/10.1007/s00264015-2725-7

63. Hernigou P, Flouzat Lachaniette CH, Delambre J, Zilber S, Duffiet P, Chevallier N, Rouard H (2014) Biologic augmentation of rotator cuff repair with mesenchymal stem cells during arthroscopy improves healing and prevents further tears: a case-controlled study. Int Orthop 38:1811-1818. https://doi.org/10.1007/s00264-0142391-1

64. Chang L, Yan Y, Wang L (2020) Coronavirus disease 2019: coronaviruses and blood safety. Transfus Med Rev. https://doi. org/10.1016/j.tmrv.2020.02.003

65. Jarajapu YP (2020) Targeting ACE2/angiotensin-(1-7)/mas receptor axis in the vascular progenitor cells for cardiovascular diseases. Mol Pharmacol https://doi.org/10.1124/mol.119.117580

66. Schäfer R, Spohn G, Bechtel M, Bojkova D, Baer PC, Kuçi S, Seifried E, Ciesek S, Cinatl J (2020) Human mesenchymal stromal cells are resistant to SARS-CoV-2 infection under steady-state, inflammatory conditions and in the presence of SARS-CoV-2infected cells. Stem Cell Rep S2213-6711(20):30378-30377. https://doi.org/10.1016/j.stemcr.2020.09.003

Publisher's note Springer Nature remains neutral with regard to jurisdictional claims in published maps and institutional affiliations. 